\title{
Serotonin and the regulation of mammalian energy balance
}

\author{
Michael H. Donovan and Laurence H. Tecott* \\ Department of Psychiatry, University of California San Francisco, CA, USA
}

\section{Edited by:}

Kevin W. Williams, The University of

Texas Southwestern Medical

Center, USA

Reviewed by:

Lora Heisler, University of

Cambridge, UK

Tamas L. Horvath, Yale University

School of Medicine, USA

*Correspondence:

Laurence H. Tecott, Department of Psychiatry, University of California San Francisco, 1550 4th Street San Francisco, CA 94158, USA e-mail: larry.tecott@ucsf.edu
Maintenance of energy balance requires regulation of the amount and timing of food intake. Decades of experiments utilizing pharmacological and later genetic manipulations have demonstrated the importance of serotonin signaling in this regulation. Much progress has been made in recent years in understanding how central nervous system (CNS) serotonin systems acting through a diverse array of serotonin receptors impact feeding behavior and metabolism. Particular attention has been paid to mechanisms through which serotonin impacts energy balance pathways within the hypothalamus. How upstream factors relevant to energy balance regulate the release of hypothalamic serotonin is less clear, but work addressing this issue is underway. Generally, investigation into the central serotonergic regulation of energy balance has had a predominantly "hypothalamocentric" focus, yet non-hypothalamic structures that have been implicated in energy balance regulation also receive serotonergic innervation and express multiple subtypes of serotonin receptors. Moreover, there is a growing appreciation of the diverse mechanisms through which peripheral serotonin impacts energy balance regulation. Clearly, the serotonergic regulation of energy balance is a field characterized by both rapid advances and by an extensive and diverse set of central and peripheral mechanisms yet to be delineated.

Keywords: serotonin, energy balance, feeding behavior, leptin, ghrelin, orexin, insulin, hypothalamus

\section{CENTRAL SEROTONIN AND ENERGY BALANCE}

The monoamine signaling molecule 5-hydroxytryptamine (5-HT, serotonin) is utilized by diverse invertebrate and vertebrate species for the regulation of many of the behavioral and physiological processes through which energy balance is maintained (Horvitz et al., 1982; Orchard, 2006; Tecott, 2007). With regard to feeding, the predominant global effect of central nervous system (CNS) serotonin signaling is the suppression of food intake. In mammals, CNS serotonin is synthesized exclusively in discrete collections of brainstem neurons known as the raphe nuclei. Serotonergic raphe neurons project widely and extensively, delivering serotonin throughout the CNS. The caudal raphe nuclei send predominantly descending projections to the brainstem and spinal cord, including to areas important for energy balance such as the nucleus of the solitary tract (NTS) and the parabrachial nuclei (PBN; Lam and Heisler, 2007). The rostral raphe nuclei, including the median and dorsal raphe, send predominantly ascending projections throughout the forebrain, including to the cortex, amygdala, striatum, hippocampus, and the various nuclei of the hypothalamus. It has long been established that most areas of the hypothalamus receive inputs from both the median and dorsal raphe (Sawchenko et al., 1983; Willoughby and Blessing, 1987; Petrov et al., 1992).

Either specific lesions of raphe nuclei or acute inhibition of these neurons by raphe injection of the gamma-aminobutyric acid receptor A (GABA-A) agonist muscimol resulted in hyperphagia and obesity (Geyer et al., 1976; Klitenick and
Wirtshafter, 1988). Furthermore pharmacological perturbation of serotonin synthesis by intracerebroventricular (ICV) injection of either the serotonergic neurotoxin 5,7-dihydroxytriptamine (5,7-DHT) or the tryptophan hydroxylase (TPH) inhibitor p-chlorophenylalanine (PCPA) have also been found to produce hyperphagia (Breisch et al., 1976; Saller and Stricker, 1976).

Conversely, central injections of serotonin or its precursor 5-hydroxytryptophan (5HTP) caused hypophagia (Blundell and Latham, 1979; Fletcher and Burton, 1986; Simansky, 1996; Yamada et al., 2006) as well as increased metabolic rate (Rothwell and Stock, 1987; Le Feuvre et al., 1991). Fenfluramine, a drug that increases synaptic serotonin concentrations by inducing vesicular release and inhibiting reuptake, also produced hypophagia, reducing meal size, and increasing inter-meal intervals in rats (Blundell et al., 1975; Grinker et al., 1980), effects which are mediated by central serotonin (Fletcher and Burton, 1986). Additionally, metabolic rate was also increased by fenfluramine administration (Rothwell and Stock, 1987; Le Feuvre et al., 1991). Moreover, the biologically active metabolite of fenfluramine, norfenfluramine, acts directly as an agonist at several serotonin receptor subtypes (Curzon et al., 1997). Fenfluramine suppressed eating and facilitated body weight loss in humans (Rogers and Blundell, 1979; McGuirk et al., 1991), and was combined with phentermine, a catecholamine/serotonin releasing agent in "FenPhen," a widely prescribed weight loss treatment. "Fen-Phen" was removed from the market in 1997 due to its promotion of cardiac valvulopathies, now attributed to action at 5HT2B receptors 
expressed on cardiac valves (Fitzgerald et al., 2000; Rothman et al., 2000).

While a preponderance of evidence points to the inhibition of feeding by serotonin, there are a few recent results that are difficult to square with such a simple model. These include several genetic perturbations of the serotonin system as well as pharmacological manipulation of several different serotonin receptors (5HTRs; discussed in a subsequent section). Interpretation of adult phenotypes in the genetic models is complicated by the fact that serotonin has significant roles in development (Alenina et al., 2009). A recent study found that mice lacking expression of the CNS serotonin synthetic enzyme TPH2 displayed decreased food consumption and body weight (Yadav et al., 2009). However, other studies of independently generated TPH2 knockout mice reported mixed results. Some have also reported modest decreases in body weight or body fat (Gutknecht et al., 2008; Savelieva et al., 2008), while others have found no differences (Alenina et al., 2009; Liu et al., 2011). Two additional studies utilizing different genetic manipulations that result in depleted serotonin also reported no changes in body weight (Hendricks et al., 2003; Narboux-Neme et al., 2011).

A second line of evidence at odds with the notion that experimentally enhancing serotonin inhibits feeding involves genetic manipulation of the serotonin reuptake transporter (SERT or 5HTT). As expected, the absence of serotonin reuptake into presynaptic terminals enhanced synaptic concentrations of serotonin, and SERT null mice exhibited elevated extracellular serotonin levels (Mathews et al., 2004). Interestingly, though, mice lacking SERT had an adult-onset obesity phenotype (Warden et al., 2005; Murphy and Lesch, 2008). While these mice were not hyperphagic, they were hypoactive, with reduced home-cage locomotor activity (Holmes et al., 2002). The phenotype was reversed for transgenic mice that overexpress SERT at 2-3 fold normal levels, with a consequent decrease in brain extracellular serotonin (Jennings et al., 2006). These mice had reduced body weight and also no alteration in feeding (Pringle et al., 2008).

It seems likely that some of the discrepancies between pharmacological and genetic manipulations of serotonin systems reflect differences between acute effects on one hand and chronic or possibly developmental effects on the other. It is worth noting that many of the transgenic mice with dramatic reductions in serotonin synthesis exhibited relatively minor behavioral abnormalities during adulthood (Savelieva et al., 2008). This rather surprising result raises the possibility that there may be some significant compensatory mechanisms at work in serotonergic target neurons or downstream feeding circuits.

\section{THE 5HT2C RECEPTOR}

Serotonin exerts its effects through actions involving at least 18 different 5HTRs, all but one of which are G-protein coupled receptors (Marston et al., 2011). Within the hypothalamus, no serotonin receptor is more highly expressed than the 5HT2CR (Yadav et al., 2009). A role for 5HT2CR-mediated signaling in energy balance was first indicated by studies showing that a nonspecific serotonin receptor agonist with high affinity at 5HT2CRs, $\mathrm{m}$-chlorophenylpiperazine ( $\mathrm{mCPP}$ ) decreased feeding and that this effect was blocked by non-selective antagonists with high affinities for the 5HT2CR (Kennett and Curzon, 1988, 1991; Kitchener and Dourish, 1994). The anorectic action of 5HT2CR was subsequently confirmed through studies of 5HT2CR knockout mice that lacked functional 5HT2CRs. These animals displayed chronic hyperphagia leading to late onset obesity (Tecott et al., 1995; Nonogaki et al., 1998). Moreover, they exhibited reduced sensitivity to the anorectic effects of dexfenfluramine (Vickers et al., 1999).

The natural course of obesity development in 5HT2CR knockout mice is reminiscent of common forms of human obesity. These animals display chronic hyperphagia (Tecott et al., 1995; Nonogaki et al., 1998), however, they do not develop obesity until 5-6 months of age (Nonogaki et al., 1998), possibly because they also exhibit enhanced home cage locomotor activity. Although the hyperlocomotor phenotype persists in older 5HT2CR knockout mice, their development of late onset obesity may be attributable to progressive increases in the energy efficiency of locomotor activity with increasing age (Nonogaki et al., 2003). These animals also display enhanced sensitivity to the obesigenic effects of high-fat feeding, including the development of type 2 diabetes mellitus (Nonogaki et al., 1998). Moreover, detailed analysis of behavior patterns in 5HT2CR null mice revealed that their hyperphagia occurred during a portion of the light cycle during which mice typically exhibit inactivity (Goulding et al., 2008). During this period, mutants were observed to exhibit multiple brief periods of activity characterized by visits to the feeder. This pattern of multiple brief feeding episodes during the inactive portion of the circadian cycle is reminiscent of the human night-eating syndrome, a condition responsive to serotonin reuptake blockade (O'Reardon et al., 2006). Altogether, a number of features of the obesity syndrome in 5HT2CR knockout mice resemble common forms of human obesity: (1) chronic hyperphagia, (2) lack of primary perturbations of metabolic rate, (3) lack of primary perturbations of the regulation of hormones implicated in energy balance, (4) late-onset, (5) exacerbation by high levels of dietary fat, and (6) a circadian pattern resembling the human night-eating syndrome. The multiple lines of evidence indicating a prominent role of 5HT2CRs in the serotonergic suppression of feeding led this receptor to be targeted for the development of agonists for obesity treatment. Recently, the 5HT2CR-specific agonist lorcaserin became the first FDA approved anti-obesity drug in 13 years (Lam et al., 2008; Thomsen et al., 2008; Hurren and Berlie, 2011).

Another intriguing feature of 5HT2CR biology relates to epigenetic modification of the $H t r 2 c$ gene product; it is one of a limited number of identified gene products known to be subject to RNA editing (Rula and Emeson, 2007). Editing occurs at five adenosine bases (editing sites A-E) within a 13 base span of exon $\mathrm{V}$ of the Htr2c gene, in a protein-coding region corresponding to the second intracellular loop of the receptor (Burns et al., 1997). This edited region is regarded as critical for signal transduction through G-protein mediated intracellular pathways (Werry et al., 2008). The edited region is also located close to a splice donor site, and alternative splicing at this site produces a truncated non-functional gene product lacking part of exon $\mathrm{V}$ (Htr2c-tr) (Canton et al., 1996; Xie et al., 1996). There are 32 
possible editing combinations arising from these 5 sites, resulting in 24 possible amino acid sequences, ranging from the non-edited (INI) to the fully edited (VGV) form. 5HT2CR RNA editing has functional consequences: generally, an inverse relationship exists between the extent of editing and 5HT2CR constitutive activity (Burns et al., 1997; Herrick-Davis et al., 1999; Niswender et al., 1999).

Several lines of evidence implicate perturbations of 5HT2CR RNA editing in the marked hyperphagia associated with PraderWilli Syndrome (PWS), a developmental disorder resulting from loss of paternal gene expression on chromosome 15q11-13. The disorder is characterized by cognitive impairment, short stature, and hyperphagia often leading to morbid obesity (Nicholls and Knepper, 2001; Goldstone, 2004). Intriguingly, the deleted region of 15q11-13 encodes multiple copies of SNORD115 (also known as H/MBII-52), a small nucleolar RNA (snoRNA) containing an 18 nucleotide anti-sense box complementary to the edited region of 5HT2CR pre-mRNA. Moreover, SNORD115 can modulate both 5HT2CR editing and alternative splicing (de los Santos et al., 2000; Cavaille et al., 2001). Consistent with a potential role for perturbation of 5HT2CR editing in the pathophysiology of PWS, brain samples from PWS patients exhibited altered editing patterns (Kishore and Stamm, 2006). Moreover, a line of mice bearing a deletion of Snord115 exhibited altered 5HT2CR editing patterns, perturbations of feeding and additional behaviors relevant to PWS (Doe et al., 2009). Another line of mice solely expressing the fully edited isoform of 5HT2CR also exhibited disorders of feeding and additional behaviors relevant to PWS (Morabito et al., 2010). Finally, leptin deficient $o b / o b$ mice have been recently found to exhibit perturbations of 5HT2CR editing within the hypothalamus, raising the possibility that the regulation of 5HT2CR editing may be sensitive to energy balance perturbations (Schellekens et al., 2012). It will be of great interest to determine in future studies the extent to which 5HT2CR RNA editing processes are sensitive to energy status.

\section{SEROTONIN AND THE HYPOTHALAMUS}

While many areas of the brain have demonstrated roles in transmitting and integrating energy balance signals, the hypothalamus is pivotal. This small region of the limbic system also has a central role in mediating stress responses, regulating body temperature, thirst and sleep, and establishing circadian rhythms. It is bordered by the third ventricle and the highly vascularized median eminence, an area with a porous blood-brain barrier. This makes it ideally positioned to sense and respond to a myriad of circulating hormones and nutrients (Rodriguez et al., 2010). The hypothalamus also receives major innervation from the NTS, a brainstem structure that relays signals transmitted via the vagus nerve from the gastrointestinal tract and other visceral organs (Sawchenko et al., 1985; Cunningham and Sawchenko, 1988). Additionally, various areas of the hypothalamus receive a wide range of projections from other areas of the brain involved in energy balance, including other brainstem nuclei, olfactory cortex, and rewardrelated areas such as the ventral striatum (Gao and Horvath, 2007).

Early experiments in rats examining the effects of discrete lesions of hypothalamic subregions reported an interesting functional division between the medial and lateral hypothalamus: lesions of medial nuclei including the paraventricular (PVH), dorsomedial (DMH), and ventromedial (VMH) nuclei produced hyperphagia and obesity while lesions within the lateral hypothalamic area (LHA) produced hypophagia (Hetherington and Ranson, 1940; Brobeck et al., 1943; Anand and Brobeck, 1951). This led to the hypothesis that the hypothalamus consisted of two centers with opposing influences on behavior: a satiety center, located medially and a feeding center, located laterally. Experiments utilizing the molecular and genetic tools of subsequent decades have demonstrated that hypothalamic physiology is somewhat more complex, integrating diverse signals reflecting short- and long-term energy stores, ingestion and digestion, circadian patterns, and environmental cues to dictate when and how much feeding occurs as well as to modulate activity and metabolic rate.

One population of neurons that seems to have an especially significant role in mediating energy balance signals is located in the arcuate nucleus and expresses proopiomelanocortin (POMC). The arcuate nucleus is located at the highly vascularized ventromedial aspect of the hypothalamus, immediately adjacent to the median eminence, allowing access to a wide range of circulating factors (Cone et al., 2001; Rodriguez et al., 2010). POMC neurons within the arcuate play an important role in sensing and integrating these peripheral factors (Williams et al., 2011). The POMC protein is enzymatically cleaved into several secreted peptides, including alpha melanocyte-stimulating hormone ( $\alpha \mathrm{MSH})$ (Cone, 2005). $\alpha \mathrm{MSH}$ is released onto downstream neurons in the DMH, VMH, PVH, and LHA, where it serves as an agonist for melanocortin receptors (MCR), in particular MC3R and MC4R (Adan et al., 1994). Genetic disruption of either POMC or MC4R has been shown to produce a dramatic increases in feeding and weight gain, indicating that a primary function of this melanocortin system is anorectic (Huszar et al., 1997; Krude et al., 1998).

POMC neurons of the arcuate nucleus express 5HT2CRs (Heisler et al., 2003; Lam et al., 2008) and both 5HT2CR agonists and d-fenfluramine stimulate POMC neuronal activity (Heisler et al., 2002). Furthermore, the hypophagia and weight loss produced by these serotonergic agents are suppressed by either genetic or pharmacological inactivation of melanocortin circuits (Heisler et al., 2002, 2003; Nonogaki and Kaji, 2010). The requirement for both an intact melanocortin circuit and functional 5HT2C receptors (Vickers et al., 1999) for the anorectic effectiveness of fenfluramine led to the hypothesis that 5HT2CR on POMC neurons may play a particularly important role in mediating the energy balance effects of serotonin. This hypothesis has been largely confirmed in recent studies (Xu et al., 2008, 2010a). These studies utilized a transgenic strategy whereby 5HT2CRs were expressed specifically on POMC neurons in an otherwise 5HT2CR null background. 5HT2CR expression solely on POMC neurons ameliorated energy balance phenotypes of 5HT2CR null mice including: hyperphagia, sensitivity to diet-induced obesity, locomotor hyperactivity, insulin resistance, and insensitivity to the anorectic effects of serotonin agonists (Xu et al., 2008, $2010 \mathrm{a}, \mathrm{b})$. Given the presence of 5HT2CRs on other neuronal populations involved in energy balance, it is somewhat surprising that 
receptors solely on POMC neurons were sufficient for restoration of normal energy balance. While this strategy demonstrates that POMC 5HT2CRs were sufficient to ameliorate phenotypes resulting from Htr $2 c$ gene inactivation, it will also be of interest to determine whether they are necessary for intact energy balance regulation in an otherwise normal brain. That is, whether inactivation of 5HT2CRs specifically on POMC neurons will produce energy balance phenotypes similar to those observed in the mice globally lacking 5HT2CRs.

In addition to POMC cells, a second type of arcuate nucleus neuron has been implicated in serotonergic control of energy balance. These neurons produce agouti-related peptide (AgRP), an endogenous antagonist of MC3R and MC4R (Nijenhuis et al., 2001; Chai et al., 2003), as well as gamma-aminobutyric acid GABA and neuropeptide Y (NPY), both of which inhibit POMC neurons and downstream melanocortin target neurons (Cowley et al., 2001). The net result of both of these effects is orexigenic behavior. Central administration of NPY or overexpression of AgRP increased food consumption leading to obesity (Stanley and Leibowitz, 1985; Ollmann et al., 1997). Interestingly genetic AgRP and NPY nulls, as well as double nulls, did not produce the expected hypophagia phenotype (Erickson et al., 1996; Qian et al., 2002). However, experiments utilizing complex genetic tools to inducibly ablate AgRP neurons, revealed that ablation during adulthood, but not neonatally, produced extreme hypophagia, rapidly leading to starvation (Gropp et al., 2005; Luquet et al., 2005). These results indicated that significant compensation likely occurred in the AgRP null mice, highlighting the redundancy in these systems and therefore the importance of robust pro-feeding circuits to an animal's survival.

5HT1BRs are expressed in arcuate nucleus AgRP neurons and have been implicated in their regulation. When expressed on serotonergic neurons, the $\mathrm{G}_{\mathrm{i}}$-coupled $5 \mathrm{HT} 1 \mathrm{BR}$ acts as an autoreceptor, inhibiting adenylyl cyclase, hyperpolarizing the neuron, and decreasing serotonin release (Kroeze et al., 2002). 5HT1BRs expressed on non-serotonin neurons can act by similar mechanisms to inhibits release of other neurotransmitters (Heisler et al., 2006). Treatment with a 5HT1BR agonist produced hypophagia and satiety (Halford and Blundell, 1996; Lee and Simansky, 1997). 5HT1BR null mice did not exhibit enhanced adiposity (Bouwknecht et al., 2001). Interestingly, though, genetic or pharmacological inactivation of 5HT1BR blunted responses to d-fenfluramine, suggesting that 5HT1BR and 5HT2CR may act cooperatively to mediate the effects of serotonin on feeding (Lucas et al., 1998; Simansky and Nicklous, 2002; Lee et al., 2004). Studies of feeding patterns indicated that the two receptors may inhibit feeding in somewhat different ways, with 5HT2CR primarily affecting the frequency with which meals are taken and 5HT1BR primarily affecting meal duration (Simansky and Vaidya, 1990; Grignaschi and Samanin, 1992). Heisler and colleagues have established a model of a cooperative relationship between 5HT2CR and 5HT1BR in the arcuate nucleus (Heisler et al., 2006). They found that 5HT1BRs are expressed on AgRP neurons, and that a 5HT1BR agonist produced opposite effects on AgRP and POMC neurons, inhibiting AgRP neurons while exciting POMC neurons. Furthermore, they found that the anorectic effects of 5HT1BR agonists required MC4R. From these data, the authors proposed a model, in which serotonin stimulates the melanocortin system by way of two parallel processes, acting through 5HT2C receptors to directly excite POMC neurons and through 5HT1B receptors to suppress GABA inhibition of POMC neurons by AgRP neurons (Heisler et al., 2006).

While both 5HT2CR and 5HT1BR have anorexigenic effects, other serotonin receptors may promote feeding. Two of these, 5HT1AR and 5HT2BR have recently been reported to exert such effects via mechanisms involving POMC neurons. Early indications of orexigenic function came from studies using 5HT1AR agonists and antagonists. Agonists of 5HT1AR produced hyperphagia while antagonists produced hypophagia (Gilbert et al., 1988; Neill and Cooper, 1988; Moreau et al., 1992). Because $5 \mathrm{HT} 1 \mathrm{AR}$ is known to play a prominent role as an inhibitory autoreceptor on serotonergic neurons, these orexigenic effects had been widely attributed to the inhibition of serotonin release. This interpretation has been complicated by a recent study utilizing a POMC-specific knockout of 5HT1AR. This study presented evidence that genetic mutation of 5HT1AR specifically in POMC neurons reduced food intake leading to reduced body weight at 6 months of age (Yadav et al., 2011). This group also reported that a POMC-specific knockout 5HT2BR produced mild hypophagia and a reduction in fat pad mass (Yadav et al., 2009). These effects were attributed to receptors on POMC neurons in the arcuate nucleus. However, POMC is also expressed peripherally, including in cardiomyocytes (Millington et al., 1999). Constitutive mutation of the 5HT2BR resulted in decreased survival and differentiation of cardiomyocytes and was associated with global developmental perturbations (Nebigil et al., 2000). This raises the possibility that the absence of 5HT2BR in peripheral POMC-expressing cells in the heart or elsewhere could contribute to the reduction in body weight reported by Yadav et al.

Like all 5HT2Rs, 5HT2BR is thought to be $\mathrm{G}_{\mathrm{q}}$-coupled and therefore excitatory, while POMC neurons have a well-established anorexigenic function (Kroeze et al., 2002). The mechanisms through which 5HT2BRs on POMC neurons may produce orexigenic effects have not been established. Reports that 5HT1AR and 5HT2BR on POMC neurons mediate orexigenic effects are especially puzzling since a series of studies recently reported that expression of 5HT2CR on POMC neurons has a critical anorexigenic function (Xu et al., 2008, 2010a). Whether and how multiple types of serotonin receptors might be working at cross-purposes in the same or different population of POMC neurons are open questions which requires additional attention.

\section{EXTRAHYPOTHALAMIC CENTRAL SEROTONIN}

While substantial advances have been made in understanding how serotonin modulates hypothalamic energy balance pathways, there are additional central sites of serotonin action that also warrant consideration. Early indications that serotonin receptors in brainstem nuclei are important for energy balance arose from studies demonstrating that $\mathrm{mCPP}$ and d-fenfluramine produced hypophagic effects when injected into the fourth ventricle and that a 5HT2CR antagonist injected into the fourth ventricle blocked hypophagia produced by systemic mCPP injection (Grill et al., 1997; Kaplan et al., 1998). Furthermore, the effects of mCPP 
and d-fenfluramine were observed even in decerebrate rats, where the direct control of feeding by hypothalamic or other forebrain structures was not possible (Grill et al., 1997; Kaplan et al., 1998).

Within the brainstem, the PBN has particular relevance to energy balance regulation. The PBN receives taste and visceral inputs relayed through the NTS. Interestingly, it also has been shown to receive serotonergic innervation from the dorsal raphe (Petrov et al., 1992). This is unusual, since the vast majority of projections from the dorsal raphe are to the forebrain. Moreover, a substantial number of dorsal raphe neurons were reported to send collateral projections to both the PBN and the PVH in the hypothalamus (Petrov et al., 1992). Neurons of the PBN express both 5HT2CR and 5HT1BR (Bruinvels et al., 1993; Wright et al., 1995). 5HT1BR agonists infused directly into the PBN were found to produce hypophagia, while antagonists attenuated systemic d-fenfluramine-induced hypophagia (Simansky and Nicklous, 2002). Findings such as these indicate that a complete understanding of the serotonergic regulation of energy balance must take into account the functions of brainstem serotonergic circuits.

Another extra-hypothalamic effect of serotonin occurs through the 5HT6 receptor, which is expressed most abundantly in the striatum (Ruat et al., 1993; Ward et al., 1995). Systemic administration 5HT6R antagonists produced hypophagia (Woolley et al., 2001; Perez-Garcia and Meneses, 2005; Heal et al., 2008). Hypophagia also occurred as a result of inactivation of 5HT6R by anti-sense oligonucleotides (Woolley et al., 2001). While genetic nulls of 5HT6R did not exhibit abnormal food consumption on standard chow (Bonasera et al., 2006), they seemed to be resistant to diet-induced obesity when fed a high-fat diet (Frassetto et al., 2008). Taken together, these results indicate that like 5HT1AR and 5HT2BR, 5HT6R signaling produces orexigenic behavior. This again highlights the complexity of serotonergic regulation of energy balance.

\section{FACTORS AFFECTING CENTRAL SEROTONIN SYNTHESIS AND RELEASE}

A full understanding of the serotonergic regulation of energy balance requires not only an appreciation of mechanisms through which serotonin-responsive central circuits influence physiological and behavioral determinants of energy balance; it also requires elucidation of the manner in which central serotonergic pathways respond to the organism's nutritional status, circulating nutrients, energy balance hormones, and environmental stimuli.

Serotonin is synthesized from the amino acid tryptophan, which is acquired from the diet, in a two-step process. The ratelimiting step is catalyzed by one of two TPH enzymes, TPH1, which acts exclusively in the periphery, and $\mathrm{TPH} 2$, which is expressed primarily in the brain (Fitzpatrick, 1999; Walther et al., 2003; Sakowski et al., 2006). In the CNS, excess serotonin is cleared from the synapse by reuptake into presynaptic terminals via SERT. As serotonin does not cross the blood-brain barrier, central and peripheral serotonin form two distinct pools (Woolley and Shaw, 1954; Merritt et al., 1978). In the brain, serotonin synthesis has been demonstrated to depend on the availability of circulating tryptophan, which is transported across the bloodbrain barrier by the L-type amino acid transporter (Fernstrom and Wurtman, 1971; Fernstrom, 2012). Administration of a tryptophan-free diet resulted in a rapid decrease in brain serotonin (Reilly et al., 1997). Conversely, systemic administration of tryptophan increased levels of serotonin and its metabolite 5-HIAA in the brain (Fernstrom and Wurtman, 1971; Schwartz et al., 1990b; Esteban et al., 2004) and also decreased food intake (Morris et al., 1987).

Hypothalamic serotonin is reportedly increased by feeding and decreased by food-restriction (Schwartz et al., 1989, 1990a; Haider and Haleem, 2000). Interestingly though, one study found that when fasted rats were exposed to the sight and smell of food, hypothalamic serotonin concentrations rose to near-maximal levels even before consumption began (Schwartz et al., 1990a) That serotonin levels increased in anticipation of feeding as well as in response to food, indicated that serotonin release in the hypothalamus is not simply a reflection of tryptophan intake during a meal.

A more complex model to explain the relationship between circulating tryptophan and central serotonin has also been proposed. In this scheme, brain serotonin synthesis is dependent not only on levels of circulating tryptophan, but also on levels of other long neutral amino acids (LNAA) that compete with tryptophan for transport into the brain. High tryptophan:LNAA ratios promote central serotonin synthesis, while low tryptophan:LNAA ratios have the opposite effect. Protein-rich meals have been shown to decrease this ratio, while carbohydrate-rich meals increased it, presumably by stimulating insulin release, which in turn promoted absorption of LNAAs by peripheral tissues (Lyons and Truswell, 1988). This mechanism may account for differences in brain serotonin levels measured after consumption of either a high-protein or high-carbohydrate diet (Schweiger et al., 1989). While the utility of such a regulatory mechanism is not clear, one model suggests that hypothalamic serotonin may serve as a feedback sensor to maintain a consistent balance of macronutrients in the diet (Leibowitz and Alexander, 1998).

\section{LEPTIN AND SEROTONIN}

Leptin is an adipocyte hormone known to play a key role in the regulation of energy balance. Circulating leptin levels are well-correlated with levels of adiposity and are believed to provide the CNS with an important indication of body fat stores (Frederich et al., 1995; Considine et al., 1996). Null mutation of the leptin gene $(\mathrm{Ob})$ produced significant hyperphagia and severe obesity (Pelleymounter et al., 1995; Chua et al., 1996). Leptin signals through several different receptor isoforms, and in the CNS, the long-form LEPRb predominates (Chua et al., 1996; Elmquist et al., 1998). While leptin does act in the periphery, its actions within the brain are believed to be particularly critical in regulating energy balance (de Luca et al., 2005). LEPRb is expressed in many regions of the brain, and particularly high levels of expression are found in the arcuate, $\mathrm{DMH}$, and $\mathrm{VMH}$ (Elmquist et al., 1998), including several populations of neurons that also express serotonin receptors. In the arcuate, LEPRb is expressed in both POMC and AgRP neurons, where they produce the opposite effects, stimulating POMC neurons and inhibiting AgRP neurons (Elias et al., 1999; Cowley et al., 2001). Like serotonin acting through $5 \mathrm{HT} 2 \mathrm{CR}$ and $5 \mathrm{HT} 1 \mathrm{BR}$, therefore, leptin is 
able to stimulate melanocortin signaling by two parallel pathways. Selective elimination of LEPRb on either POMC or AgRP neurons produced a mild obesity phenotype (Balthasar et al., 2004; van de Wall et al., 2008). Interestingly, selective elimination of LEPRb in the steroid factor 1 (SF1)-expressing neurons of the VMH also produced an obesity phenotype, with a cumulative effect in mice lacking LEPRb in both SF1 and POMC neurons, indicating that these may represent distinct parallel pathways (Dhillon et al., 2006; Kim et al., 2011b).

Given their presumably disparate roles in reflecting short-term satiety (serotonin) vs. long-term energy stores (leptin), it has been proposed that serotonin and leptin might represent independent energy-balance systems that integrate in the hypothalamus (Halford and Blundell, 2000). In support of separate but coordinated action of serotonin and leptin, the obesity phenotype of leptin-overexpressing mice on a high-fat diet was exacerbated in the absence of 5HT2CR (Wang and Chehab, 2006). Since 5HT2CR is expressed on both POMC and SF1 neurons (Heisler et al., 2003; Yadav et al., 2009), these represent two potential sites where serotonin and leptin signaling might be integrated. Interestingly, though, a recent study of POMC neurons in the arcuate found that 5HT2CR and LEPRb were expressed on separate populations of POMC neurons, indicating that integration may occur elsewhere (Sohn et al., 2011).

Some recent studies provide evidence that a complex interplay may occur between these two systems. One study examining the impact of combined $\mathrm{Htr} 2 \mathrm{c}$ null and $o b / o b$ leptin null mutations revealed a synergistic effect on glucose regulation, indicated by a marked exacerbation of the diabetes phenotype characteristic of the ob/ob genotype (Wade et al., 2008). Early indications that leptin might have a direct effect on serotonin function arose from several histological studies demonstrating that long-form leptin receptor (LEPRb) is expressed in neurons of the raphe nuclei (Elmquist et al., 1998; Mercer et al., 1998; Shioda et al., 1998) where it co-localizes with SERT, a marker of serotonin-producing neurons in the raphe (Collin et al., 2000; Finn et al., 2001). Furthermore, serotonergic neurons of the dorsal raphe have been shown to take up a labeled leptin analog infused into the lateral ventricle, a phenomenon indicative of LEPRb binding and internalization (Fernandez-Galaz et al., 2002). However, a comprehensive analysis of leptin receptor co-localization with serotonin using multiple histochemical techniques including independently generated LepRb reporter mice failed to detect any co-localization with serotonin (Lam et al., 2011).

Evidence for a functional interaction between serotonin and leptin arose from studies demonstrating that central or peripheral leptin administration altered serotonin levels in the brainstem and hypothalamus (Harris et al., 1998; Calapai et al., 1999) Studies by Yamada et al. provided interesting evidence for regulation in the reciprocal direction; treatment with the serotonin precursor 5HTP increased circulating leptin levels (Yamada et al., 1999, 2006). It is unclear whether this effect is mediated by central or peripheral serotonin, as peripheral 5HTP administration affects both. In support of serotonin enhancing leptin levels, SERT null mice, which exhibit globally increased extracellular serotonin levels, have increased serum leptin levels (Chen et al., 2012). Treatment with the TPH2 inhibitor PCPA, which reduces serotonin synthesis and release, increased uptake of leptin in both the hypothalamus and brainstem, providing evidence that serotonin not only regulates leptin release, but also its uptake into the brain (Fernandez-Galaz et al., 2010). Another study by Yamada et al. demonstrated that serotonin may be required for some leptin-mediated influences on energy-balance; PCPA treatment abolished a decrease in refeeding caused by an i.p. leptin injection in fasted mice (Yamada et al., 2003), although this was not replicated in another study which demonstrated that significant serotonin depletion with PCPA had no effect on leptin-induced hypophagia (Lam et al., 2011). This effect was recapitulated by treatment with a $5 \mathrm{HT} 2 \mathrm{~B} / 2 \mathrm{C}$ receptor antagonist, although not by either 5HT2AR or 5HT1BR antagonists, indicating that either $5 \mathrm{HT} 2 \mathrm{BR}$ or $5 \mathrm{HT} 2 \mathrm{CR}$ are required for leptin-induced anorexia.

A model in which leptin actions are mediated through serotonergic circuits has recently been proposed by Yadav et al. (2009, 2011). They propose that leptin-mediated suppression of feeding occurs via inhibition of raphe serotonergic neurons. The central experiment of this study utilized a transgenic strategy to eliminate LEPRb specifically in SERT-expressing cells. This manipulation increased food intake, body weight, and body fat and decreased energy expenditure and bone mass (Yadav et al., 2009). Additionally, these mice exhibited reduced hypothalamic expression of anorexigenic melanocortin genes MC4R and POMC and increased expression or orexigenic NPY and AgRP, indicating downregulation of the melanocortin system (Yadav et al., 2009). The degree of perturbation of feeding, body weight, adiposity, metabolism, and gene expression in SERT-specific LEPRb null mice was virtually indistinguishable from $o b / o b$ leptin null mice, and POMC- or SF1-specific LEPRb null mice did not display significant alterations in any of these parameters (Yadav et al., 2009). Furthermore, the authors demonstrated that a homozygous (or even a heterozygous) TPH2 null mutation rescued the perturbed feeding and metabolism of leptin null mice (Yadav et al., 2009).

These results conflict with the prevailing notion that leptin exerts its effects on energy balance predominantly through other neuronal populations including POMC neurons of the arcuate (Balthasar et al., 2004; Coppari et al., 2005; van de Wall et al., 2008) and SF1 neurons of the VMH (Dhillon et al., 2006). Consistent with the prevailing notion, a subsequent paper by Lam et al. found that serotonergic neurons in the dorsal raphe neither expressed LEPRb nor were sensitive to leptin, and that depletion of central serotonin with PCPA did not interfere with leptininduced hypophagia. Furthermore, they reported that, in their hands, SERT-specific LEPRb null mice had no changes in body weight or adiposity (Lam et al., 2011).

In response to concern that the SERT-driver mouse might have produced inactivation of LEPRb outside the serotonergic neurons of the brainstem, a follow-up study by Yadav et al. utilized a tamoxifen-inducible TPH2-driver (Yadav et al., 2011). This allowed inducible inactivation of LEPRb is adult mice, obviating concerns regarding developmental effects in non-serotonergic neurons. A similar phenotype was observed: inducible TPH2specific LEPRb null mice displayed increased body weight, fat pad weight, food intake, and decreased metabolic rate, darkcycle locomotor activity, and hypothalamic expression of MC4R 
and POMC (Yadav et al., 2011). However, in the absence of independent confirmation, these results remain controversial.

\section{GHRELIN AND SEROTONIN}

Ghrelin is a gastric hormone that is secreted during periods of fasting, and its levels fall after food intake (Kojima et al., 1999; Date et al., 2000; Tschop et al., 2000). Ghrelin treatment has been shown to increase food intake and chronic administration to result in obesity (Tschop et al., 2000; Wren et al., 2000). Interestingly, there is also evidence that ghrelin is synthesized in a small population of neurons in the arcuate nucleus ( $\mathrm{Lu}$ et al., 2002; Cowley et al., 2003). The function of hypothalamic ghrelin synthesis is not clear. Peripheral ghrelin crosses the blood-brain barrier, and the arcuate nucleus appears to be an important site for its action. Ghrelin receptors (growth hormone secretagogue receptor, GHSR) are expressed on AgRP neurons, where they mediate excitatory effects (Willesen et al., 1999; Wang et al., 2002). Accordingly, central ghrelin administration activated AgRP neurons and inhibited POMC neurons (Cowley et al., 2003; Riediger et al., 2003). Furthermore, knockout of either MC3R and MC4R or NPY and AgRP produced significant attenuation of the orexigenic effects of peripheral ghrelin (Chen et al., 2004), while ablation of AgRP neurons completely eliminates the effects of ghrelin (Bewick et al., 2005). Ghrelin and serotonin signals appear to produce opposing effects in arcuate nucleus neuronal populations.

Evidence also exists indicating that serotonergic signaling may impact ghrelin release. Both fenfluramine and mCPP decreased plasma active ghrelin levels without altering hypothalamic ghrelin gene expression (Nonogaki et al., 2006). Subsequent work has demonstrated that fenfluramine alters gut motility through a ghrelin-dependent mechanism, inducing motility patterns characteristic of a fed state in fasted rats (Fujitsuka et al., 2009). Furthermore, these effects were shown to be dependent on 5HT2CR but not on MC4R. The authors proposed a model in which 5HT2CR activation decreases gut motility by inhibiting ghrelin release, presumably through descending sympathetic input to the stomach (Fujitsuka et al., 2009). Since serotonin acting in the hypothalamus has been demonstrated to stimulate growth hormone $(\mathrm{GH})$ release from the pituitary (Vijayan et al., 1978; Willoughby et al., 1987), and GH is known to downregulate production of stomach ghrelin (Nonogaki, 2008), it is also possible that serotonin decreases circulating ghrelin by stimulating GH release. However, another study utilizing hypothalamus explants found that $\mathrm{mCPP}$ decreased ghrelin secretion from the hypothalamus itself (Yakabi et al., 2010). There is also evidence that ghrelin can influence serotonin release in both the hypothalamus and hippocampus (Brunetti et al., 2002; Ghersi et al., 2011).

\section{INSULIN AND SEROTONIN}

Insulin is secreted by the $\beta$-cells of the pancreas in response to rising blood glucose levels and it promotes glucose uptake and utilization by peripheral tissues. However insulin also acts in the brain, where it has effects on glucoregulation and energy balance (Woods et al., 1979; Konner et al., 2007; Hill et al., 2010). In the brain, insulin has been shown to act as an anorexigenic hormone: ICV infusion produced hypophagia and weight loss, while a CNS-specific insulin receptor knockout mouse line exhibited obesity (Woods et al., 1979; Bruning et al., 2000). Insulin and serotonin receptors co-localize in several key nuclei of the hypothalamus. Of particular interest, insulin has been demonstrated to act directly on both POMC and AgRP neurons of the arcuate (Konner et al., 2007; Hill et al., 2010). Interestingly, leptin- and insulin-responsive POMC neurons reportedly represent two distinct populations (Williams et al., 2010), and the same has been reported for leptin- and serotonin-responsive neurons (Sohn et al., 2011). It is not yet clear whether 5HT2CR cells are also insulin-responsive. Insulin receptor activation may inhibit the function of 5HT2CR intracellularly in cells expressing both receptors. This has been demonstrated in choroid plexus cells to occur via MAP kinase inactivation of 5HT2CR (Hurley et al., 2003). It is possible that a similar mechanism exists within POMC neurons.

Several lines of evidence now indicate that serotonin and insulin are not merely parallel activators of melanocortin circuits, but that there is an interaction between the two systems. For example, systemic administration of 5HT2CR agonists decreased serum insulin at doses that did not impact food intake or body weight (Zhou et al., 2007). This effect was demonstrated to occur via an MC4R dependent-mechanism. Additionally, Orosco et al. reported that an infusion of fenfluramine directly into the hypothalamus increased hypothalamic extracellular insulin levels (Orosco et al., 2000). In support of a more general effect, systemic dexfenfluramine treatment increased serum insulin levels (Papazoglou et al., 2012). SERT-deficient mice have increased serum insulin as well as increased pancreatic islet cell density and other morphological changes indicative of increased insulin production (Chen et al., 2012).

\section{OREXIN AND SEROTONIN}

Orexin neurons are located in the lateral hypothalamus and project widely throughout the brain. Serotonergic neurons of the dorsal raphe nucleus express orexin receptors (Marcus et al., 2001; Wang et al., 2005). Serotonergic raphe neurons receive a particularly dense innervation from orexin neurons (Peyron et al., 1998; Nambu et al., 1999; Brown et al., 2002). Moreover, serotonergic neurons were found to be stimulated by orexin administration in a raphe slice preparation (Brown et al., 2002; Liu et al., 2002). However, this effect may not have occurred solely through direct activation of orexin receptors on serotonin neurons. Another study has shown that orexin inhibited excitatory glutamatergic input to dorsal raphe serotonin neurons via a retrograde endocannabinoid signal (Haj-Dahmane and Shen, 2005). Behavioral effects produced by orexin administration were blocked by 5HT2AR and 5HT2CR antagonists (Duxon et al., 2001; Matsuzaki et al., 2002), raising the possibility that serotonergic systems contribute to the behavioral actions of orexin.

There is also evidence that serotonin systems can directly impact the function of orexin neurons. Orexin neurons in the lateral hypothalamus express 5HT1A receptors and serotonergic nerve terminals are in close apposition to orexin neurons (Muraki et al., 2004). Additionally, administration of serotonin and 5HT1AR agonists inhibited orexin neurons (Muraki et al., 
2004). Functionally, mice lacking orexin neurons did not exhibit 5HT1AR antagonist-induced hyperlocomotion (Muraki et al., 2004). Another study found that impaired expression of both orexin and POMC by RNA interference abolished the hypophagia produced by mCPP treatment, while reduced expression of either gene alone had no effect (Nonogaki and Kaji, 2010). Taken together, these results indicate that orexin neurons may play a role in mediating the anorexigenic effects of 5HT2CR or 5HT1BR stimulation, as well as the hyperlocomotor effects of 5HT1AR activation.

\section{PERIPHERAL SEROTONIN}

In mammals, the vast majority of serotonin resides not in the brain, but in the periphery (Erspamer, 1966). In contrast to the CNS, where serotonin is synthesized only by a small number of neurons in a few discrete nuclei, peripheral serotonin is produced by both neurons and non-neuronal cells in a wide variety of tissues. However, by far the largest quantity of serotonin resides within the gut, in specialized endocrine cells, called enterocromaffin cells that synthesize and store large quantities of serotonin (Erspamer, 1966). Serotonin release by these cells is stimulated by the presence of food and in turn, serotonin stimulates gut motility (Racke et al., 1996; Fujimiya et al., 1997; Kidd et al., 2008). This circuit is therefore critical for proper absorption of nutrients.

Enterochromaffin cells are found in the enteric epithelium throughout the length of the digestive track (Erspamer, 1966). These cells release moderate levels of serotonin constitutively and large quantities in response to various relevant factors including decreased $\mathrm{pH}$ and mechanical pressure (Racke et al., 1996; Fujimiya et al., 1997). Serotonin is released primarily into the underlying connective tissue layer of the mucosa, which is innervated by nerve terminals of the primary sensory neurons of the enteric nervous system. From there, high concentrations of serotonin spill over into both the circulatory system and the intestinal lumen (Gronstad et al., 1985; Nilsson et al., 1987; Fujimiya et al., 1997; Bearcroft et al., 1998). Furthermore, it has been demonstrated that SERT is widely expressed on enteric epithelial cells, allowing them to clear excess serotonin, preventing 5HTR desensitization (Wade et al., 1996; Chen et al., 1998). Mice lacking functional SERT have excessive gut motility and gastrointestinal dysfunction (Chen et al., 2001).

The primary sensory neurons of the enteric submucosa are cholinergic and their function is required for the proper peristaltic and secretory responses to food (Cooke et al., 1997; Pan and Gershon, 2000). Their dendritic terminals extend into the mucosa and respond to serotonin via an as yet unidentified receptor, known as 5HT1P (Branchek et al., 1988; Wade et al., 1991). These neurons synapse onto cholinergic interneurons within the myenteric plexus, which in turn synapse onto excitatory and inhibitory motor neurons, causing rhythmic peristalsis (Grider et al., 1996). Presynaptic 5HT4R receptors at both of these synapses enhance neurotransmitter release (Pan and Galligan, 1994; Galligan et al., 2003). Stimulation of 5HT1P seems to be important in initiating peristalsis in response to a food bolus, while $5 \mathrm{HT} 4 \mathrm{R}$ is involved in maintaining peristalsis once it has begun (Grider et al., 1996; Gershon, 2004, 2005). There is also evidence for serotonin causing smooth muscle contraction in the stomach fundus via 5HT2BR located directly on smooth muscle cells (Kursar et al., 1994; Depoortere et al., 2006).

5 HT3 receptors are expressed on nerve terminals of vagal afferents located in the gastrointestinal track, where they respond to serotonin released by enterochromaffin cells (Glatzle et al., 2002; Raybould et al., 2003). These afferents mediate sensations of gastric discomfort and nausea, and 5HT3R antagonists are effective anti-emetic drugs (Gershon, 2004, 2005). Some of these vagal afferents make connections with regions of the brain important to energy balance. Serotonin release resulting from gastric distension led to increased neuronal activity in regions including the NTS and PVH (Mazda et al., 2004). This effect was blocked by either truncal vagotomy or peripheral (but not central) administration of a 5HT3R antagonist (Mazda et al., 2004).

Some serotonin released by enterochromaffin cells is absorbed into the circulation by capillaries in the enteric submucosa, where it enters the blood stream (Tamir et al., 1985; Bearcroft et al., 1998). This serves as the primary source of circulating serotonin (Bertaccini, 1960) and levels of plasma serotonin increase after a meal (Bearcroft et al., 1998; Houghton et al., 2003). In the blood, serotonin is taken up by platelets, which express SERT (Tamir et al., 1985; Ni and Watts, 2006). Serotonin stored in platelets serves as an important reservoir for peripheral serotonin. The inability of serotonin to cross the blood-brain barrier limits the ability of circulating serotonin fluctuation to impact energy balance circuits in the CNS (Woolley and Shaw, 1954; Merritt et al., 1978). However, circulating serotonin acting in the periphery has many important functions, some of which relate to energy balance. Like central infusion of serotonin, peripheral administration of serotonin decreased food consumption and accelerated satiety (Fletcher and Burton, 1986; Edwards and Stevens, 1991).

Circulating serotonin has also been shown to have complex effects on peripheral glucose regulation. Peripheral serotonin seems to impact glucoregulation via at least two discrete apparently opposing mechanisms. Peripheral serotonin administration has been found in some studies to increase, and in others to decrease circulating blood glucose levels, with the discrepancy possibly depending on dose, route, or other conditions (Yamada et al., 1989, 1995; Sugimoto et al., 1990). Serotonin-induced hyperglycemia is likely due to inhibition of glucose uptake by the liver and muscle tissue (Hajduch et al., 1999; Moore et al., 2005). Conversely, peripheral serotonin also produced hyperinsulinemia, an action promoting reduction of glucose levels. This effect presumably occurs via stimulation of pancreatic $\beta$-cells by serotonin. $\beta$-cells actually synthesize and store serotonin (Ekholm et al., 1971) and recent evidence indicated that an interesting mechanism may at least partially underlie regulation of insulin release by serotonin. Serotonin in $\beta$-cells has been reported to act intracellularly via a 5HTR-independent mechanism, whereby serotonin directly binds to and activates small GTPase molecules to stimulate insulin secretion (Paulmann et al., 2009).

In addition, circulating serotonin influences lipid metabolism. Peripheral administration of serotonin accelerated lipid metabolism, decreasing circulating levels of triglycerides, fatty acids, and cholesterol (Watanabe et al., 2010). This has been 
attributed to increased release and turnover of bile acid (Bogach and Liashchenko, 1976; Watanabe et al., 2010). Functional relevance is lent to this finding by another recent study showing that blood serotonin was substantially elevated in diet-induced obese mice (Kim et al., 2011a).

\section{CONCLUSION}

In conclusion, the extent to which central and peripheral serotonin signaling pervasively impact the regulation of energy balance is quite remarkable. It is challenging to identify central or peripheral neural mechanisms of energy balance regulation that are NOT sensitive to serotonergic modulation. The use of mouse genetic models with cell-type-specific patterns of gene inactivation is contributing substantially to rapid progress in this field. The most extensively characterized of the serotonergic influences on energy balance pathways relates to the modulation of arcuate nucleus POMC and NPY/AgRP neuronal populations. Clearly, this has significant functional relevance. However, the serotonergic innervation of additional hypothalamic regions and the expression of multiple 5HTR subtypes in these regions

\section{REFERENCES}

Adan, R. A., Cone, R. D., Burbach, J. P., and Gispen, W. H. (1994). Differential effects of melanocortin peptides on neural melanocortin receptors. Mol. Pharmacol. 46, 1182-1190.

Alenina, N., Kikic, D., Todiras, M., Mosienko, V., Qadri, F., Plehm, R., et al. (2009). Growth retardation and altered autonomic control in mice lacking brain serotonin. Proc. Natl. Acad. Sci. U.S.A. 106, 10332-10337.

Anand, B. K., and Brobeck, J. R. (1951). Localization of a "feeding center" in the hypothalamus of the rat. Proc. Soc. Exp. Biol. Med. 77, 323-324.

Balthasar, N., Coppari, R., McMinn, J., Liu, S. M., Lee, C. E., Tang, V., et al. (2004). Leptin receptor signaling in POMC neurons is required for normal body weight homeostasis. Neuron 42, 983-991.

Bearcroft, C. P., Perrett, D., and Farthing, M. J. (1998). Postprandial plasma 5-hydroxytryptamine in diarrhoea predominant irritable bowel syndrome: a pilot study. Gut 42, 42-46.

Bertaccini, G. (1960). Tissue 5hydroxytryptamine and urinary 5-hydroxyindoleacetic acid after partial or total removal of the gastro-intestinal tract in the rat. J. Physiol. 153, 239-249.

Bewick, G. A., Gardiner, J. V., Dhillo, W. S., Kent, A. S., White, N. E., Webster, Z., et al. (2005). Post-embryonic ablation of AgRP neurons in mice leads to a lean, hypophagic phenotype. FASEB J. 19, 1680-1682.

Blundell, J. E., Campbell, D. B., Lesham, M., and Tozer, R. (1975). Comparison of the time course of the anorectic effect of fenfluramine and amphetamine with drug levels in blood. J. Pharm. Pharmacol. 27, 187-192.

Blundell, J. E., and Latham, C. J. (1979). Serotonergic influences on food intake: effect of 5-hydroxytryptophan on parameters of feeding behaviour in deprived and free-feeding rats. Pharmacol. Biochem. Behav. 11,

Bogach, P. G., and Liashchenko, P. S. (1976). [The effect of serotonin on bile secretion in dogs]. Fiziol. Zh. SSSR Im. I M Sechenova 62, 283-288.

Bonasera, S. J., Chu, H. M., Brennan, T. J., and Tecott, L. H. (2006). A null mutation of the serotonin 6 receptor alters acute responses to ethanol. Neuropsychopharmacology 31, 1801-1813.

Bouwknecht, J. A., Van Der Gugten, J., Hijzen, T. H., Maes, R. A., Hen, R., and Olivier, B. (2001). Male and female 5-HT(1B) receptor knockout mice have higher body weights than wildtypes. Physiol. Behav. 74, 507-516.

Branchek, T. A., Mawe, G. M., and Gershon, M. D. (1988). Characterization and localization of a peripheral neural 5-hydroxytryptamine receptor subtype (5-HT1P) with a selective 431-437.

suggest that much remains to be learned regarding serotonergic regulation of hypothalamic energy balance pathways other than those originating the arcuate nucleus. Also important, but less understood, are mechanisms through which serotonin systems regulate energy balance pathways in caudal brainstem regions such as the NTS and PBN. In addition to advances in understanding how serotonergic inputs influence energy balance pathways, new light is being shed on mechanisms through which energy balance hormones influence the activity of serotonin systems. It is also becoming clear that serotonergic influences on hypothalamic energy balance pathways interact with those mediated by leptin, ghrelin, and insulin. Evidence that serotonin systems can influence circulating levels of these hormones indicates an additional level of complexity with regard to the interplay of these signaling molecules in energy balance regulation. Finally, newly uncovered roles for central and peripheral serotonin in the regulation of glucose homeostasis and lipid metabolism underscore the pervasive involvement of serotonin signaling in the interplay between central and peripheral mechanisms of energy balance regulation.

agonist, 3H-5-hydroxyindalpine. J. Neurosci. 8, 2582-2595.

Breisch, S. T., Zemlan, F. P., and Hoebel, B. G. (1976). Hyperphagia and obesity following serotonin depletion by intraventricular pchlorophenylalanine. Science 192, 382-385.

Brobeck, J. R., Tepperman, J., and Long, C. N. (1943). Experimental hypothalamic hyperphagia in the albino rat. Yale J. Biol. Med. 15, 831-853.

Brown, R. E., Sergeeva, O. A., Eriksson, K. S., and Haas, H. L. (2002). Convergent excitation of dorsal raphe serotonin neurons by multiple arousal systems (orexin/hypocretin, histamine and noradrenaline). J. Neurosci. 22, 8850-8859.

Bruinvels, A. T., Palacios, J. M., and Hoyer, D. (1993). 5-hydroxytryptaminel recognition sites in rat brain: heterogeneity of non-5hydroxytryptamine1A/1C binding sites revealed by quantitative receptor autoradiography. Neuroscience 53, 465-473.

Brunetti, L., Recinella, L., Orlando, G., Michelotto, B., Di Nisio, C., and Vacca, M. (2002). Effects of ghrelin and amylin on dopamine, norepinephrine and serotonin release in the hypothalamus. Eur. J. Pharmacol. 454, 189-192.

Bruning, J. C., Gautam, D., Burks, D. J., Gillette, J., Schubert, M., Orban, P. C., et al. (2000). Role of brain insulin receptor in control of body weight and reproduction. Science 289, 2122-2125.
Burns, C. M., Chu, H., Rueter, S. M., Hutchinson, L. K., Canton, H., Sanders-Bush, E., et al. (1997). Regulation of serotonin-2C receptor G-protein coupling by RNA editing. Nature 387, 303-308.

Calapai, G., Corica, F., Corsonello, A., Sautebin, L., Di Rosa, M., Campo, G. M., et al. (1999). Leptin increases serotonin turnover by inhibition of brain nitric oxide synthesis. J. Clin. Invest. 104, 975-982.

Canton, H., Emeson, R. B., Barker, E. L., Backstrom, J. R., Lu, J. T., Chang, M. S., et al. (1996). Identification, molecular cloning, and distribution of a short variant of the 5hydroxytryptamine2C receptor produced by alternative splicing. Mol. Pharmacol. 50, 799-807.

Cavaille, J., Vitali, P., Basyuk, E., Huttenhofer, A., and Bachellerie, J. P. (2001). A novel brain-specific box C/D small nucleolar RNA processed from tandemly repeated introns of a noncoding RNA gene in rats. J. Biol. Chem. 276, 26374-26383.

Chai, B. X., Neubig, R. R., Millhauser, G. L., Thompson, D. A., Jackson, P. J., Barsh, G. S., et al. (2003). Inverse agonist activity of agouti and agouti-related protein. Peptides 24, 603-609.

Chen, H. Y., Trumbauer, M. E., Chen, A. S., Weingarth, D. T., Adams, J. R., Frazier, E. G., et al. (2004). Orexigenic action of peripheral ghrelin is mediated by neuropeptide $\mathrm{Y}$ and agouti-related protein. Endocrinology 145, 2607-2612.

Chen, J. J., Li, Z., Pan, H., Murphy, D. L., Tamir, H., Koepsell, H., et al. 
(2001). Maintenance of serotonin in the intestinal mucosa and ganglia of mice that lack the high-affinity serotonin transporter: abnormal intestinal motility and the expression of cation transporters. J. Neurosci. 21, 6348-6361.

Chen, J. X., Pan, H., Rothman, T. P., Wade, P. R., and Gershon, M. D. (1998). Guinea pig 5-HT transporter: cloning, expression, distribution, and function in intestinal sensory reception. Am. J. Physiol. 275, G433-G448.

Chen, X., Margolis, K. J., Gershon, M. D., Schwartz, G. J., and Sze, J. Y. (2012). Reduced serotonin reuptake transporter (SERT) function causes insulin resistance and hepatic steatosis independent of food intake. PLOS ONE 7:e32511. doi: 10.1371/journal.pone.0032511

Chua, S. C. Jr., Chung, W. K., Wu-Peng, X. S., Zhang, Y., Liu, S. M., Tartaglia, L., et al. (1996). Phenotypes of mouse diabetes and rat fatty due to mutations in the OB (leptin) receptor. Science 271, 994-996.

Collin, M., Hakansson-Ovesjo, M. L., Misane, I., Ogren, S. O., and Meister, B. (2000). Decreased 5-HT transporter mRNA in neurons of the dorsal raphe nucleus and behavioral depression in the obese leptindeficient ob/ob mouse. Brain Res. Mol. Brain Res. 81, 51-61.

Cone, R. D. (2005). Anatomy and regulation of the central melanocortin system. Nat. Neurosci. 8, 571-578.

Cone, R. D., Cowley, M. A., Butler, A. A., Fan, W., Marks, D. L., and Low, M. J. (2001). The arcuate nucleus as a conduit for diverse signals relevant to energy homeostasis. Int. J. Obes. Relat. Metab. Disord. 25(Suppl. 5), S63-S67.

Considine, R. V., Sinha, M. K., Heiman, M. L., Kriauciunas, A., Stephens, T. W., Nyce, M. R., et al. (1996). Serum immunoreactive-leptin concentrations in normal-weight and obese humans. N. Engl. J. Med. 334, 292-295.

Cooke, H. J., Sidhu, M., and Wang, Y. Z. (1997). 5-HT activates neural reflexes regulating secretion in the guinea-pig colon. Neurogastroenterol. Motil. 9, 181-186.

Coppari, R., Ichinose, M., Lee, C. E., Pullen, A. E., Kenny, C. D., McGovern, R. A., et al. (2005). The hypothalamic arcuate nucleus: a key site for mediating leptin's effects on glucose homeostasis and locomotor activity. Cell Metab. 1, 63-72.

Cowley, M. A., Smart, J. L., Rubinstein, M., Cerdan, M. G., Diano, S., Horvath, T. L., et al. (2001). Leptin activates anorexigenic POMC neurons through a neural network in the arcuate nucleus. Nature 411, 480-484.

Cowley, M. A., Smith, R. G., Diano, S., Tschop, M., Pronchuk, N., Grove, K. L., et al. (2003). The distribution and mechanism of action of ghrelin in the CNS demonstrates a novel hypothalamic circuit regulating energy homeostasis. Neuron 37, 649-661.

Cunningham, E. T. Jr., and Sawchenko, P. E. (1988). Anatomical specificity of noradrenergic inputs to the paraventricular and supraoptic nuclei of the rat hypothalamus. J. Comp. Neurol. 274, 60-76.

Curzon, G., Gibson, E. L., and Oluyomi, A. O. (1997). Appetite suppression by commonly used drugs depends on 5-HT receptors but not on 5-HT availability. Trends Pharmacol. Sci. 18, 21-25.

Date, Y., Kojima, M., Hosoda, H., Sawaguchi, A., Mondal, M. S., Suganuma, T., et al. (2000). Ghrelin, a novel growth hormone-releasing acylated peptide, is synthesized in a distinct endocrine cell type in the gastrointestinal tracts of rats and humans. Endocrinology 141, 4255-4261.

de los Santos, T., Schweizer, J., Rees, C. A., and Francke, U. (2000). Small evolutionarily conserved RNA, resembling C/D box small nucleolar RNA, is transcribed from PWCR1, a novel imprinted gene in the Prader-Willi deletion region, which Is highly expressed in brain. Am. J. Hum. Genet. 67, 1067-1082.

de Luca, C., Kowalski, T. J., Zhang, Y., Elmquist, J. K., Lee, C., Kilimann, M. W., et al. (2005). Complete rescue of obesity, diabetes, and infertility in $\mathrm{db} / \mathrm{db}$ mice by neuron-specific LEPR-B transgenes. J. Clin. Invest. 115, 3484-3493.

Depoortere, I., Thijs, T., and Peeters, T. (2006). The contractile effect of the ghrelin receptor antagonist, D-Lys3-GHRP-6, in rat fundic strips is mediated through 5 -HT receptors. Eur. J. Pharmacol. 537, 160-165.

Dhillon, H., Zigman, J. M., Ye, C., Lee, C. E., McGovern, R. A., Tang, V., et al. (2006). Leptin directly activates $\mathrm{SF} 1$ neurons in the $\mathrm{VMH}$, and this action by leptin is required for normal body-weight homeostasis. Neuron 49, 191-203.

Doe, C. M., Relkovic, D., Garfield, A. S., Dalley, J. W., Theobald, D. E., Humby, T., et al. (2009). Loss of the imprinted snoRNA mbii-52 leads to increased 5 htr2c pre-RNA editing and altered 5HT2CR-mediated behaviour. Hum. Mol. Genet. 18, 2140-2148.

Duxon, M. S., Stretton, J., Starr, K., Jones, D. N., Holland, V., Riley, G., et al. (2001). Evidence that orexin-A-evoked grooming in the rat is mediated by orexin-1 (OX1) receptors, with downstream 5-HT2C receptor involvement. Psychopharmacology (Berl.) 153, 203-209.

Edwards, S., and Stevens, R. (1991). Peripherally administered 5hydroxytryptamine elicits the full behavioural sequence of satiety. Physiol. Behav. 50, 1075-1077.

Ekholm, R., Ericson, L. E., and Lundquist, I. (1971). Monoamines in the pancreatic islets of the mouse. Subcellular localization of 5-hydroxytryptamine by electron microscopic autoradiography. Diabetologia 7, 339-348.

Elias, C. F., Aschkenasi, C., Lee, C. Kelly, J., Ahima, R. S., Bjorbaek, C., et al. (1999). Leptin differentially regulates NPY and POMC neurons projecting to the lateral hypothalamic area. Neuron 23, 775-786.

Elmquist, J. K., Bjorbaek, C., Ahima, R. S., Flier, J. S., and Saper, C. B. (1998). Distributions of leptin receptor mRNA isoforms in the rat brain. J. Comp. Neurol. 395, 535-547.

Erickson, J. C., Clegg, K. E., and Palmiter, R. D. (1996). Sensitivity to leptin and susceptibility to seizures of mice lacking neuropeptide Y. Nature 381, 415-421.

Erspamer, V. (1966). Handbook of Experimental Pharmacology: 5Hydroxytryptamine and Related Indolealkylamines, Vol. 19. New York, NY: Springer-Verlag.

Esteban, S., Nicolaus, C., Garmundi, A., Rial, R. V., Rodriguez, A. B., Ortega, E., et al. (2004). Effect of orally administered L-tryptophan on serotonin, melatonin, and the innate immune response in the rat. Mol. Cell Biochem. 267, $39-46$.

Fernandez-Galaz, M. C., Diano, S., Horvath, T. L., and Garcia-Segura, L. M. (2002). Leptin uptake by serotonergic neurones of the dorsal raphe. J. Neuroendocrinol. 14, 429-434.

Fernandez-Galaz, M. C., FernandezAgullo, T., Carrascosa, J. M., Ros, M., and Garcia-Segura, L. M. (2010). Leptin accumulation in hypothalamic and dorsal raphe neurons is inversely correlated with brain serotonin content. Brain Res. 1329, 194-202.

Fernstrom, J. D. (2012). Large neutral amino acids: dietary effects on brain neurochemistry and function. Amino Acids. doi: 10.1007/s00726012-1330-y. [Epub ahead of print].

Fernstrom, J. D., and Wurtman, R. J. (1971). Brain serotonin content: physiological dependence on plasma tryptophan levels. Science 173, 149-152.

Finn, P. D., Cunningham, M. J., Rickard, D. G., Clifton, D. K., and Steiner, R. A. (2001). Serotonergic neurons are targets for leptin in the monkey. J. Clin. Endocrinol. Metab. $86,422-426$.

Fitzgerald, L. W., Burn, T. C., Brown, B. S., Patterson, J. P., Corjay, M. H., Valentine, P. A., et al. (2000). Possible role of valvular serotonin 5 -HT(2B) receptors in the cardiopathy associated with fenfluramine. Mol. Pharmacol. 57, 75-81.

Fitzpatrick, P. F. (1999). Tetrahydropterin-dependent amino acid hydroxylases. Annu. Rev. Biochem. 68, 355-381.

Fletcher, P. J., and Burton, M. J. (1986). Microstructural analysis of the anorectic action of peripherally administered 5-HT. Pharmacol. Biochem. Behav. 24, 1133-1136.

Frassetto, A., Zhang, J., Lao, J. Z., White, A., Metzger, J. M., Fong, T. M., et al. (2008). Reduced sensitivity to diet-induced obesity in mice carrying a mutant 5-HT6 receptor. Brain Res. 1236, 140-144.

Frederich, R. C., Hamann, A., Anderson, S., Lollmann, B., Lowell, B. B., and Flier, J. S. (1995). Leptin levels reflect body lipid content in mice: evidence for diet-induced resistance to leptin action. Nat. Med. 1, 1311-1314.

Fujimiya, M., Okumiya, K., and Kuwahara, A. (1997). Immunoelectron microscopic study of the luminal release of serotonin from rat enterochromaffin cells induced by high intraluminal pressure. Histochem. Cell Biol. 108, 105-113.

Fujitsuka, N., Asakawa, A., Hayashi, M., Sameshima, M., Amitani, H. Kojima, S., et al. (2009). Selective serotonin reuptake inhibitors modify physiological gastrointestinal motor activities via 5-HT2c receptor and acyl ghrelin. Biol. Psychiatry 65, 748-759.

Galligan, J. J., Pan, H., and Messori, E. (2003). Signalling mechanism coupled to 5-hydroxytryptamine4 receptor-mediated facilitation of fast synaptic transmission in the guinea-pig ileum myenteric plexus. Neurogastroenterol. Motil. 15, 523-529.

Gao, Q., and Horvath, T. L. (2007). Neurobiology of feeding and energy 
expenditure. Annu. Rev. Neurosci. 30, 367-398.

Gershon, M. D. (2004). Review article: serotonin receptors and transporters - roles in normal and abnormal gastrointestinal motility. Aliment. Pharmacol. Ther. 20(Suppl. 7), 3-14.

Gershon, M. D. (2005). Nerves, reflexes, and the enteric nervous system: pathogenesis of the irritable bowel syndrome. J. Clin. Gastroenterol. 39, S184-S193.

Geyer, M. A., Puerto, A., Menkes, D. B., Segal, D. S., and Mandell, A. J. (1976). Behavioral studies following lesions of the mesolimbic and mesostriatal serotonergic pathways. Brain Res. 106, 257-269.

Ghersi, M. S., Casas, S. M., Escudero, C., Carlini, V. P., Buteler, F., Cabrera, R. J., et al. (2011). Ghrelin inhibited serotonin release from hippocampal slices. Peptides 32, 2367-2371.

Gilbert, F., Dourish, C. T., Brazell, C., McClue, S., and Stahl, S. M. (1988). Relationship of increased food intake and plasma ACTH levels to 5-HT1A receptor activation in rats. Psychoneuroendocrinology 13, 471-478.

Glatzle, J., Sternini, C., Robin, C., Zittel, T. T., Wong, H., Reeve, J. R. Jr., et al. (2002). Expression of 5-HT3 receptors in the rat gastrointestinal tract. Gastroenterology 123, 217-226.

Goldstone, A. P. (2004). Prader-Willi syndrome: advances in genetics, pathophysiology and treatment. Trends Endocrinol. Metab. 15, 12-20.

Goulding, E. H., Schenk, A. K., Juneja, P., Mackay, A. W., Wade, J. M., and Tecott, L. H. (2008). A robust automated system elucidates mouse home cage behavioral structure. Proc. Natl. Acad. Sci. U.S.A. 105, 20575-20582.

Grider, J. R., Kuemmerle, J. F., and Jin, J. G. (1996). 5-HT released by mucosal stimuli initiates peristalsis by activating 5-HT4/5-HT1p receptors on sensory CGRP neurons. Am. J. Physiol. 270, G778-G782.

Grignaschi, G., and Samanin, R. (1992). Role of 5-HT receptors in the effect of d-fenfluramine on feeding patterns in the rat. Eur. J. Pharmacol. 212, 287-289.

Grill, H. J., Donahey, J. C., King, L., and Kaplan, J. M. (1997). Contribution of caudal brainstem to d-fenfluramine anorexia. Psychopharmacology (Berl.) 130, 375-381.

Grinker, J. A., Drewnowski, A., Enns, M., and Kissileff, H. (1980). Effects of d-amphetamine and fenfluramine on feeding pattens and activity of obese and lean Zucker rats. Pharmacol. Biochem. Behav. 12, 265-275.

Gronstad, K. O., Demagistris, L., Dahlstrom, A., Nilsson, O., Price, B., Zinner, M. J., et al. (1985). The effects of vagal nerve stimulation on endoluminal release of serotonin and substance $\mathrm{P}$ into the feline small intestine. Scand. J. Gastroenterol. 20, 163-169.

Gropp, E., Shanabrough, M., Borok, E., Xu, A. W., Janoschek, R., Buch, T., et al. (2005). Agoutirelated peptide-expressing neurons are mandatory for feeding. Nat. Neurosci. 8, 1289-1291.

Gutknecht, L., Waider, J., Kraft, S., Kriegebaum, C., Holtmann, B., Reif, A., et al. (2008). Deficiency of brain 5-HT synthesis but serotonergic neuron formation in $\mathrm{Tph} 2$ knockout mice. J. Neural Transm. 115, 1127-1132.

Haider, S., and Haleem, D. J. (2000). Decreases of brain serotonin following a food restriction schedule of 4 weeks in male and female rats. Med. Sci. Monit. 6, 1061-1067.

Haj-Dahmane, S., and Shen, R. Y. (2005). The wake-promoting peptide orexin-B inhibits glutamatergic transmission to dorsal raphe nucleus serotonin neurons through retrograde endocannabinoid signaling. J. Neurosci. 25, 896-905.

Hajduch, E., Rencurel, F., Balendran, A., Batty, I. H., Downes, C. P., and Hundal, H. S. (1999). Serotonin (5Hydroxytryptamine), a novel regulator of glucose transport in rat skeletal muscle. J. Biol. Chem. 274, 13563-13568.

Halford, J. C., and Blundell, J. E. (1996). The 5-HT1B receptor agonist CP-94, 253 reduces food intake and preserves the behavioural satiety sequence. Physiol. Behav. 60, 933-939.

Halford, J. C., and Blundell, J. E. (2000). Separate systems for serotonin and leptin in appetite control. Ann. Med. 32, 222-232.

Harris, R. B., Zhou, J., Redmann, S. M. Jr., Smagin, G. N., Smith, S. R., Rodgers, E., et al. (1998). A leptin dose-response study in obese $(\mathrm{ob} / \mathrm{ob})$ and lean $(+/$ ?) mice. Endocrinology 139, 8-19.

Heal, D. J., Smith, S. L., Fisas, A., Codony, X., and Buschmann, H. (2008). Selective 5-HT6 receptor ligands: progress in the development of a novel pharmacological approach to the treatment of obesity and related metabolic disorders. Pharmacol. Ther. 117, 207-231.

Heisler, L. K., Cowley, M. A., Kishi, T., Tecott, L. H., Fan, W., Low, M.
J., et al. (2003). Central serotonin and melanocortin pathways regulating energy homeostasis. Ann. N.Y. Acad. Sci. 994, 169-174.

Heisler, L. K., Cowley, M. A., Tecott, L. H., Fan, W., Low, M. J., Smart, J. L., et al. (2002). Activation of central melanocortin pathways by fenfluramine. Science 297, 609-611.

Heisler, L. K., Jobst, E. E., Sutton, G. M., Zhou, L., Borok, E., ThorntonJones, Z., et al. (2006). Serotonin reciprocally regulates melanocortin neurons to modulate food intake. Neuron 51, 239-249.

Hendricks, T. J., Fyodorov, D. V., Wegman, L. J., Lelutiu, N. B., Pehek, E. A., Yamamoto, B., et al. (2003). Pet-1 ETS gene plays a critical role in 5-HT neuron development and is required for normal anxiety-like and aggressive behavior. Neuron 37, 233-247.

Herrick-Davis, K., Grinde, E., and Niswender, C. M. (1999). Serotonin 5-HT2C receptor RNA editing alters receptor basal activity: implications for serotonergic signal transduction. J. Neurochem. 73, 1711-1717.

Hetherington, A. W., and Ranson, S. W. (1940). Hypothalamic lesions and adiposity in the rat. Anat. Rec. 78, 149.

Hill, J. W., Elias, C. F., Fukuda, M., Williams, K. W., Berglund, E. D., Holland, W. L., et al (2010). Direct insulin and leptin action on pro-opiomelanocortin neurons is required for normal glucose homeostasis and fertility. Cell Metab. 11, 286-297.

Holmes, A., Murphy, D. L., and Crawley, J. N. (2002). Reduced aggression in mice lacking the serotonin transporter. Psychopharmacology (Berl.) 161, 160-167.

Horvitz, H. R., Chalfie, M., Trent, C. Sulston, J. E., and Evans, P. D. (1982). Serotonin and octopamine in the nematode Caenorhabditis elegans. Science 216, 1012-1014.

Houghton, L. A., Atkinson, W., Whitaker, R. P., Whorwell, P. J., and Rimmer, M. J. (2003). Increased platelet depleted plasma 5-hydroxytryptamine concentration following meal ingestion in symptomatic female subjects with diarrhoea predominant irritable bowel syndrome. Gut 52, 663-670.

Hurley, J. H., Zhang, S., Bye, L. S., Marshall, M. S., Depaoli-Roach, A. A., Guan, K., et al. (2003). Insulin signaling inhibits the 5HT2C receptor in choroid plexus via MAP kinase. BMC Neurosci. 4:10. doi: 10.1186/1471-2202-4-10
Hurren, K. M., and Berlie, H. D. (2011). Lorcaserin: an investigational serotonin 2C agonist for weight loss. Am. J. Health Syst. Pharm. 68, 2029-2037.

Huszar, D., Lynch, C. A., FairchildHuntress, V., Dunmore, J. H., Fang, Q., Berkemeier, L. R., et al. (1997). Targeted disruption of the melanocortin-4 receptor results in obesity in mice. Cell 88, 131-141.

Jennings, K. A., Loder, M. K., Sheward, W. J., Pei, Q., Deacon, R. M., Benson, M. A., et al. (2006). Increased expression of the 5-HT transporter confers a low-anxiety phenotype linked to decreased 5-HT transmission. J. Neurosci. 26, 8955-8964.

Kaplan, J. M., Song, S., and Grill, H. J. (1998). Serotonin receptors in the caudal brainstem are necessary and sufficient for the anorectic effect of peripherally administered mCPP. Psychopharmacology (Berl.) 137, 43-49.

Kennett, G. A., and Curzon, G. (1988). Evidence that hypophagia induced by $\mathrm{mCPP}$ and TFMPP requires 5-HT1C and 5-HT1B receptors; hypophagia induced by RU 24969 only requires 5-HT1B receptors. Psychopharmacology (Berl.) 96, 93-100.

Kennett, G. A., and Curzon, G. (1991). Potencies of antagonists indicate that 5-HT1C receptors mediate 13(chlorophenyl)piperazine-induced hypophagia. Br. J. Pharmacol. 103, 2016-2020.

Kidd, M., Modlin, I. M., Gustafsson, B. I., Drozdov, I., Hauso, O., and Pfragner, R. (2008). Luminal regulation of normal and neoplastic human EC cell serotonin release is mediated by bile salts, amines, tastants, and olfactants. Am. J. Physiol. Gastrointest. Liver Physiol. 295, G260-G272.

Kim, H. J., Kim, J. H., Noh, S., Hur, H. J., Sung, M. J., Hwang, J. T., et al. (2011a). Metabolomic analysis of livers and serum from high-fat diet induced obese mice. J. Proteome Res. 10, 722-731.

Kim, K. W., Sohn, J. W., Kohno, D., $\mathrm{Xu}, \mathrm{Y}$., Williams, K., and Elmquist, J. K. (2011b). SF-1 in the ventral medial hypothalamic nucleus: a key regulator of homeostasis. Mol. Cell Endocrinol. 336, 219-223.

Kishore, S., and Stamm, S. (2006). The snoRNA HBII-52 regulates alternative splicing of the serotonin receptor 2C. Science 311, 230-232.

Kitchener, S. J., and Dourish, C. T. (1994). An examination of the behavioural specificity of hypophagia induced by 5 -HT1B, 5-HT1C 
and 5-HT2 receptor agonists using the post-prandial satiety sequence in rats. Psychopharmacology (Berl.) 113, 369-377.

Klitenick, M. A., and Wirtshafter, D. (1988). Comparative studies of the ingestive behaviors produced by microinjections of muscimol into the midbrain raphe nuclei of the ventral tegmental area of the rat. Life Sci. 42, 775-782.

Kojima, M., Hosoda, H., Date, Y., Nakazato, M., Matsuo, H., and Kangawa, K. (1999). Ghrelin is a growth-hormone-releasing acylated peptide from stomach. Nature 402, 656-660.

Konner, A. C., Janoschek, R., Plum, L., Jordan, S. D., Rother, E., Ma, X., et al. (2007). Insulin action in AgRPexpressing neurons is required for suppression of hepatic glucose production. Cell Metab. 5, 438-449.

Kroeze, W. K., Kristiansen, K., and Roth, B. L. (2002). Molecular biology of serotonin receptors structure and function at the molecular level. Curr. Top. Med. Chem. 2, 507-528.

Krude, H., Biebermann, H., Luck, W., Horn, R., Brabant, G., and Gruters, A. (1998). Severe early-onset obesity, adrenal insufficiency and red hair pigmentation caused by POMC mutations in humans. Nat. Genet. 19, 155-157.

Kursar, J. D., Nelson, D. L., Wainscott, D. B., and Baez, M. (1994). Molecular cloning, functional expression, and mRNA tissue distribution of the human 5hydroxytryptamine2B receptor. Mol. Pharmacol. 46, 227-234.

Lam, D. D., and Heisler, L. K. (2007). Serotonin and energy balance: molecular mechanisms and implications for type 2 diabetes. Expert Rev. Mol. Med. 9, 1-24.

Lam, D. D., Leinninger, G. M., Louis, G. W., Garfield, A. S., Marston, O. J., Leshan, R. L., et al. (2011). Leptin does not directly affect CNS serotonin neurons to influence appetite. Cell Metab. 13, 584-591.

Lam, D. D., Przydzial, M. J., Ridley, S. H., Yeo, G. S., Rochford, J. J., O'Rahilly, S., et al. (2008). Serotonin 5-HT2C receptor agonist promotes hypophagia via downstream activation of melanocortin 4 receptors. Endocrinology 149, 1323-1328.

Le Feuvre, R. A., Aisenthal, L., and Rothwell, N. J. (1991). Involvement of corticotrophin releasing factor (CRF) in the thermogenic and anorexic actions of serotonin (5HT) and related compounds. Brain Res. 555, 245-250.

Lee, M. D., and Simansky, K. J. (1997). CP-94, 253: a selective serotonin1B
(5-HT1B) agonist that promotes satiety. Psychopharmacology (Berl.) 131, 264-270.

Lee, M. D., Somerville, E. M., Kennett, G. A., Dourish, C. T., and Clifton, P. G. (2004). Reduced hypophagic effects of d-fenfluramine and the 5 -HT2C receptor agonist $\mathrm{mCPP}$ in 5-HT1B receptor knockout mice. Psychopharmacology (Berl.) 176, 39-49.

Leibowitz, S. F., and Alexander, J. T. (1998). Hypothalamic serotonin in control of eating behavior, meal size, and body weight. Biol. Psychiatry 44, 851-864.

Liu, R. J., Van Den Pol, A. N., and Aghajanian, G. K. (2002). Hypocretins (orexins) regulate serotonin neurons in the dorsal raphe nucleus by excitatory direct and inhibitory indirect actions. J. Neurosci. 22, 9453-9464.

Liu, Y., Jiang, Y., Si, Y., Kim, J. Y., Chen, Z. F., and Rao, Y. (2011). Molecular regulation of sexual preference revealed by genetic studies of 5 -HT in the brains of male mice. Nature 472, 95-99.

Lu, S., Guan, J. L., Wang, Q. P., Uehara, K., Yamada, S., Goto, N., et al. (2002). Immunocytochemical observation of ghrelin-containing neurons in the rat arcuate nucleus. Neurosci. Lett. 321, 157-160.

Lucas, J. J., Yamamoto, A., ScearceLevie, K., Saudou, F., and Hen, R. (1998). Absence of fenfluramineinduced anorexia and reduced c-Fos induction in the hypothalamus and central amygdaloid complex of serotonin 1B receptor knock-out mice. J. Neurosci. 18, 5537-5544.

Luquet, S., Perez, F. A., Hnasko, T. S., and Palmiter, R. D. (2005). NPY/AgRP neurons are essential for feeding in adult mice but can be ablated in neonates. Science 310, 683-685.

Lyons, P. M., and Truswell, A. S. (1988). Serotonin precursor influenced by type of carbohydrate meal in healthy adults. Am. J. Clin. Nutr. 47, 433-439.

Marcus, J. N., Aschkenasi, C. J., Lee, C. E., Chemelli, R. M., Saper, C. B., Yanagisawa, M., et al. (2001). Differential expression of orexin receptors 1 and 2 in the rat brain. J. Comp. Neurol. 435, 6-25.

Marston, O. J., Garfield, A. S., and Heisler, L. K. (2011). Role of central serotonin and melanocortin systems in the control of energy balance. Eur. J. Pharmacol. 660, 70-79.

Mathews, T. A., Fedele, D. E., Coppelli, F. M., Avila, A. M., Murphy, D. L., and Andrews, A. M. (2004). Gene dose-dependent alterations in extraneuronal serotonin but not dopamine in mice with reduced serotonin transporter expression. J. Neurosci. Methods 140 169-181.

Matsuzaki, I., Sakurai, T., Kunii, K. Nakamura, T., Yanagisawa, M., and Goto, K. (2002). Involvement of the serotonergic system in orexininduced behavioral alterations in rats. Regul. Pept. 104, 119-123.

Mazda, T., Yamamoto, H., Fujimura M., and Fujimiya, M. (2004) Gastric distension-induced release of 5-HT stimulates c-fos expression in specific brain nuclei via 5 -HT3 receptors in conscious rats. Am. J. Physiol. Gastrointest. Liver Physiol. 287, G228-G235.

McGuirk, J., Goodall, E., Silverstone, T., and Willner, P. (1991). Differential effects of d-fenfluramine, 1fenfluramine and d-amphetamine on the microstructure of human eating behaviour. Behav. Pharmacol. 2, 113-119.

Mercer, J. G., Moar, K. M., and Hoggard, N. (1998). Localization of leptin receptor (Ob-R) messenger ribonucleic acid in the rodent hindbrain. Endocrinology 139, 29-34.

Merritt, J. H., Chamness, A. F., and Allen, S. J. (1978). Studies on blood-brain barrier permeability after microwave-radiation. Radiat. Environ. Biophys. 15, 367-377.

Millington, W. R., Rosenthal, D. W., Unal, C. B., and NyquistBattie, C. (1999). Localization of pro-opiomelanocortin mRNA transcripts and peptide immunoreactivity in rat heart. Cardiovasc. Res. 43, 107-116.

Moore, M. C., Kimura, K., Shibata, H., Honjoh, T., Saito, M., Everett, C. A., et al. (2005). Portal 5hydroxytryptophan infusion enhances glucose disposal in conscious dogs. Am. J. Physiol. Endocrinol. Metab. 289, E225-E231.

Morabito, M. V., Abbas, A. I., Hood, J. L., Kesterson, R. A., Jacobs, M. M., Kump, D. S., et al. (2010). Mice with altered serotonin $2 \mathrm{C}$ receptor RNA editing display characteristics of Prader-Willi syndrome. Neurobiol. Dis. 39, 169-180.

Moreau, J. L., Griebel, G., Jenck, F., Martin, J. R., Widmer, U., and Haefely, W. E. (1992). Behavioral profile of the 5HT1A receptor antagonist (S)-UH-301 in rodents and monkeys. Brain Res. Bull. 29, 901-904.

Morris, P., Li, E. T., Macmillan, M. L., and Anderson, G. H. (1987). Food intake and selection after peripheral tryptophan. Physiol. Behav. 40, 155-163.
Muraki, Y., Yamanaka, A., Tsujino, N., Kilduff, T. S., Goto, K., and Sakurai, T. (2004). Serotonergic regulation of the orexin/hypocretin neurons through the 5-HT1A receptor. J. Neurosci. 24, 7159-7166.

Murphy, D. L., and Lesch, K. P. (2008). Targeting the murine serotonin transporter: insights into human neurobiology. Nat. Rev. Neurosci. 9, 85-96.

Nambu, T., Sakurai, T., Mizukami, K., Hosoya, Y., Yanagisawa, M., and Goto, K. (1999). Distribution of orexin neurons in the adult rat brain. Brain Res. 827, 243-260.

Narboux-Neme, N., Sagne, C., Doly, S., Diaz, S. L., Martin, C. B., Angenard, G., et al. (2011). Severe serotonin depletion after conditional deletion of the vesicular monoamine transporter 2 gene in serotonin neurons: neural and behavioral consequences. Neuropsychopharmacology 36, 2538-2550.

Nebigil, C. G., Choi, D. S., Dierich, A., Hickel, P., Le Meur, M., Messaddeq, N., et al. (2000). Serotonin 2B receptor is required for heart development. Proc. Natl. Acad. Sci. U.S.A. 97, 9508-9513.

Neill, J. C., and Cooper, S. J. (1988) MDL 72832, a selective 5-HT1A receptor ligand, stereospecifically increases food intake. Eur. J. Pharmacol. 151, 329-332.

Ni, W., and Watts, S. W. (2006). 5hydroxytryptamine in the cardiovascular system: focus on the serotonin transporter (SERT). Clin. Exp. Pharmacol. Physiol. 33, 575-583.

Nicholls, R. D., and Knepper, J. L. (2001). Genome organization, function, and imprinting in PraderWilli and Angelman syndromes. Annu. Rev. Genomics Hum. Genet. 2, 153-175.

Nijenhuis, W. A., Oosterom, J., and Adan, R. A. (2001). AgRP(83-132) acts as an inverse agonist on the human-melanocortin-4 receptor. Mol. Endocrinol. 15, 164-171.

Nilsson, O., Ahlman, H., Geffard, M., Dahlstrom, A., and Ericson, L. E. (1987). Bipolarity of duodenal enterochromaffin cells in the rat. Cell Tissue Res. 248, 49-54.

Niswender, C. M., Copeland, S. C., Herrick-Davis, K., Emeson, R. B. and Sanders-Bush, E. (1999). RNA editing of the human serotonin 5-hydroxytryptamine $2 \mathrm{C}$ receptor silences constitutive activity. J. Biol. Chem. 274, 9472-9478.

Nonogaki, K. (2008). Ghrelin and feedback systems. Vitam. Horm. 77, 149-170.

Nonogaki, K., Abdallah, L., Goulding, E. H., Bonasera, S. J., and Tecott 
L. H. (2003). Hyperactivity and reduced energy cost of physical activity in serotonin $5-\mathrm{HT}(2 \mathrm{C})$ receptor mutant mice. Diabetes 52, 315-320.

Nonogaki, K., and Kaji, T. (2010). Hypothalamic orexin and proopiomelanocortin activities are essential for the anorexic effects of $\mathrm{m}$-chlorophenylpiperazine in mice. Int. J. Neuropsychopharmacol. 13, 1261-1267.

Nonogaki, K., Ohashi-Nozue, K., and Oka, Y. (2006). A negative feedback system between brain serotonin systems and plasma active ghrelin levels in mice. Biochem. Biophys. Res. Commun. 341, 703-707.

Nonogaki, K., Strack, A. M., Dallman, M. F., and Tecott, L. H. (1998). Leptin-independent hyperphagia and type 2 diabetes in mice with a mutated serotonin 5-HT2C receptor gene. Nat. Med. 4, 1152-1156.

O'Reardon, J. P., Allison, K. C., Martino, N. S., Lundgren, J. D., Heo, M., and Stunkard, A. J. (2006). A randomized, placebo-controlled trial of sertraline in the treatment of night eating syndrome. Am. J. Psychiatry 163, 893-898.

Ollmann, M. M., Wilson, B. D., Yang, Y. K., Kerns, J. A., Chen, Y., Gantz, I., et al. (1997). Antagonism of central melanocortin receptors in vitro and in vivo by agouti-related protein. Science 278, 135-138.

Orchard, I. (2006). Serotonin: a coordinator of feeding-related physiological events in the blood-gorging bug, Rhodnius prolixus. Comp. Biochem. Physiol. A Mol. Integr. Physiol. 144, 316-324.

Orosco, M., Rouch, C., and Gerozissis, K. (2000). Activation of hypothalamic insulin by serotonin is the primary event of the insulin-serotonin interaction involved in the control of feeding. Brain Res. 872, 64-70.

Pan, H., and Galligan, J. J. (1994). 5-HT1A and 5-HT4 receptors mediate inhibition and facilitation of fast synaptic transmission in enteric neurons. Am. J. Physiol. 266, G230-G238.

Pan, H., and Gershon, M. D. (2000). Activation of intrinsic afferent pathways in submucosal ganglia of the guinea pig small intestine. J. Neurosci. 20, 3295-3309.

Papazoglou, I., Berthou, F., Vicaire, N., Rouch, C., Markaki, E. M., Bailbe, D., et al. (2012). Hypothalamic serotonin-insulin signaling crosstalk and alterations in a type 2 diabetic model. Mol. Cell Endocrinol. $350,136-144$
Paulmann, N., Grohmann, M., Voigt, J. P., Bert, B., Vowinckel, J., Bader, M., et al. (2009). Intracellular serotonin modulates insulin secretion from pancreatic betacells by protein serotonylation. PLoS Biol. 7:e1000229. doi: 10.1371/journal.pbio.1000229

Pelleymounter, M. A., Cullen, M. J., Baker, M. B., Hecht, R., Winters, D., Boone, T., et al. (1995). Effects of the obese gene product on body weight regulation in ob/ob mice. Science 269, 540-543.

Perez-Garcia, G., and Meneses, A. (2005). Oral administration of the 5-HT6 receptor antagonists SB357134 and SB-399885 improves memory formation in an autoshaping learning task. Pharmacol. Biochem. Behav. 81, 673-682.

Petrov, T., Krukoff, T. L., and Jhamandas, J. H. (1992). The hypothalamic paraventricular and lateral parabrachial nuclei receive collaterals from raphe nucleus neurons: a combined double retrograde and immunocytochemical study. J. Comp. Neurol. 318, 18-26.

Peyron, C., Tighe, D. K., Van Den Pol, A. N., De Lecea, L., Heller, H. C., Sutcliffe, J. G., et al. (1998). Neurons containing hypocretin (orexin) project to multiple neuronal systems. J. Neurosci. 18, 9996-10015.

Pringle, A., Jennings, K. A., Line, S., Bannerman, D. M., Higgs, S., and Sharp, T. (2008). Mice overexpressing the 5-hydroxytryptamine transporter show no alterations in feeding behaviour and increased non-feeding responses to fenfluramine. Psychopharmacology (Berl.) 200, 291-300.

Qian, S., Chen, H., Weingarth, D., Trumbauer, M. E., Novi, D. E., Guan, X., et al. (2002). Neither agouti-related protein nor neuropeptide $\mathrm{Y}$ is critically required for the regulation of energy homeostasis in mice. Mol. Cell Biol. 22, 5027-5035.

Racke, K., Reimann, A., Schworer, H., and Kilbinger, H. (1996). Regulation of 5-HT release from enterochromaffin cells. Behav. Brain Res. 73, 83-87.

Raybould, H. E., Glatzle, J., Robin, C., Meyer, J. H., Phan, T., Wong, H., et al. (2003). Expression of 5HT3 receptors by extrinsic duodenal afferents contribute to intestinal inhibition of gastric emptying. Am. J. Physiol. Gastrointest. Liver Physiol. 284, G367-G372.

Reilly, J. G., McTavish, S. F., and Young, A. H. (1997). Rapid depletion of plasma tryptophan: a review of studies and experimental methodology. J. Psychopharmacol. 11, 381-392.

Riediger, T., Traebert, M., Schmid, H. A., Scheel, C., Lutz, T. A., and Scharrer, E. (2003). Site-specific effects of ghrelin on the neuronal activity in the hypothalamic arcuate nucleus. Neurosci. Lett. 341, 151-155.

Rodriguez, E. M., Blazquez, J. L. and Guerra, M. (2010). The design of barriers in the hypothalamus allows the median eminence and the arcuate nucleus to enjoy private milieus: the former opens to the portal blood and the latter to the cerebrospinal fluid. Peptides 31, 757-776.

Rogers, P. J., and Blundell, J. E. (1979). Effect of anorexic drugs on food intake and the microstructure of eating in human subjects. Psychopharmacology (Berl.) 66, 159-165.

Rothman, R. B., Baumann, M. H., Savage, J. E., Rauser, L., McBride, A., Hufeisen, S. J., et al. (2000). Evidence for possible involvement of $5-\mathrm{HT}(2 \mathrm{~B})$ receptors in the cardiac valvulopathy associated with fenfluramine and other serotonergic medications. Circulation 102, 2836-2841.

Rothwell, N. J., and Stock, M. J. (1987). Effect of diet and fenfluramine on thermogenesis in the rat: possible involvement of serotonergic mechanisms. Int. J. Obes. 11, 319-324.

Ruat, M., Traiffort, E., Arrang, J. M., Tardivel-Lacombe, J., Diaz, J. Leurs, R., et al. (1993). A novel rat serotonin (5-HT6) receptor: molecular cloning, localization and stimulation of cAMP accumulation. Biochem. Biophys. Res. Commun. 193, 268-276

Rula, E. Y., and Emeson, R. B. (2007). Mouse models to elucidate the functional roles of adenosine-toinosine editing. Methods Enzymol. 424, 333-367.

Sakowski, S. A., Geddes, T. J., Thomas, D. M., Levi, E., Hatfield, J. S., and Kuhn, D. M. (2006). Differential tissue distribution of tryptophan hydroxylase isoforms 1 and 2 as revealed with monospecific antibodies. Brain Res. 1085, $11-18$.

Saller, C. F., and Stricker, E. M. (1976). Hyperphagia and increased growth in rats after intraventricular injection of 5, 7-dihydroxytryptamine. Science 192, 385-387.

Savelieva, K. V., Zhao, S., Pogorelov, V. M., Rajan, I., Yang, Q., Cullinan, E., et al. (2008). Genetic disruption of both tryptophan hydroxylase genes dramatically reduces serotonin and affects behavior in models sensitive to antidepressants. PLoS ONE 3:e3301. doi: 10.1371/journal.pone.0003301

Sawchenko, P. E., Swanson, L. W., Grzanna, R., Howe, P. R., Bloom, S. R., and Polak, J. M. (1985). Colocalization of neuropeptide Y immunoreactivity in brainstem catecholaminergic neurons that project to the paraventricular nucleus of the hypothalamus. J. Comp. Neurol. 241, 138-153.

Sawchenko, P. E., Swanson, L. W. Steinbusch, H. W., and Verhofstad, A. A. (1983). The distribution and cells of origin of serotonergic inputs to the paraventricular and supraoptic nuclei of the rat. Brain Res. 277, 355-360.

Schellekens, H., Clarke, G., Jeffery, I. B. Dinan, T. G., and Cryan, J. F. (2012). Dynamic 5-HT2C receptor editing in a mouse model of obesity. PLoS ONE 7:e32266. doi: 10.1371/journal.pone.0032266

Schwartz, D. H., Hernandez, L., and Hoebel, B. G. (1990a). Serotonin release in lateral and medial hypothalamus during feeding and its anticipation. Brain Res. Bull. 25, 797-802.

Schwartz, D. H., Hernandez, L., and Hoebel, B. G. (1990b). Tryptophan increases extracellular serotonin in the lateral hypothalamus of fooddeprived rats. Brain Res. Bull. 25, 803-807.

Schwartz, D. H., McClane, S., Hernandez, L., and Hoebel, B. G. (1989). Feeding increases extracellular serotonin in the lateral hypothalamus of the rat as measured by microdialysis. Brain Res. 479, 349-354.

Schweiger, U., Broocks, A., Tuschl, R. J., and Pirke, K. M. (1989). Serotonin turnover in rat brain during semistarvation with high-protein and high-carbohydrate diets. J. Neural Transm. 77, 131-139.

Shioda, S., Funahashi, H., Nakajo, S., Yada, T., Maruta, O., and Nakai, Y. (1998). Immunohistochemical localization of leptin receptor in the rat brain. Neurosci. Lett. 243, 41-44.

Simansky, K. J. (1996). Serotonergic control of the organization of feeding and satiety. Behav. Brain Res. 73, 37-42.

Simansky, K. J., and Nicklous, D. M. (2002). Parabrachial infusion of D-fenfluramine reduces food intake. Blockade by the $5-\mathrm{HT}(1 \mathrm{~B})$ antagonist SB-216641. Pharmacol. Biochem. Behav. 71, 681-690.

Simansky, K. J., and Vaidya, A. H. (1990). Behavioral mechanisms for 
the anorectic action of the serotonin (5-HT) uptake inhibitor sertraline in rats: comparison with directly acting 5-HT agonists. Brain Res. Bull. 25, 953-960.

Sohn, J. W., Xu, Y., Jones, J. E., Wickman, K., Williams, K. W., and Elmquist, J. K. (2011). Serotonin 2C receptor activates a distinct population of arcuate pro-opiomelanocortin neurons via TRPC channels. Neuron 71, 488-497.

Stanley, B. G., and Leibowitz, S. F. (1985). Neuropeptide Y injected in the paraventricular hypothalamus: a powerful stimulant of feeding behavior. Proc. Natl. Acad. Sci. U.S.A. 82, 3940-3943.

Sugimoto, Y., Kimura, I., Yamada, J., Watanabe, Y., Takeuchi, N., and Horisaka, K. (1990). Effects of serotonin on blood glucose and insulin levels of glucose- and streptozotocin-treated mice. Jpn. J. Pharmacol. 54, 93-96.

Tamir, H., Payette, R. F., Huang, Y. L., Liu, K. P., and Gershon, M. D. (1985). Human serotonectin: a blood glycoprotein that binds serotonin and is associated with platelets and white blood cells. J. Cell Sci. 73, 187-206.

Tecott, L. H. (2007). Serotonin and the orchestration of energy balance. Cell Metab. 6, 352-361.

Tecott, L. H., Sun, L. M., Akana, S. F., Strack, A. M., Lowenstein, D. H., Dallman, M. F., et al. (1995). Eating disorder and epilepsy in mice lacking 5-HT2c serotonin receptors. Nature 374, 542-546.

Thomsen, W. J., Grottick, A. J., Menzaghi, F., Reyes-Saldana, H., Espitia, S., Yuskin, D., et al. (2008). Lorcaserin, a novel selective human 5-hydroxytryptamine2C agonist: in vitro and in vivo pharmacological characterization. J. Pharmacol. Exp. Ther. 325, 577-587.

Tschop, M., Smiley, D. L., and Heiman, M. L. (2000). Ghrelin induces adiposity in rodents. Nature 407, 908-913.

van de Wall, E., Leshan, R., Xu, A. W., Balthasar, N., Coppari, R., Liu, S. M., et al. (2008). Collective and individual functions of leptin receptor modulated neurons controlling metabolism and ingestion. Endocrinology 149, 1773-1785.

Vickers, S. P., Clifton, P. G., Dourish, C. T., and Tecott, L. H. (1999). Reduced satiating effect of d-fenfluramine in serotonin 5$\mathrm{HT}(2 \mathrm{C})$ receptor mutant mice. Psychopharmacology (Berl.) 143, 309-314.
Vijayan, E., Krulich, L., and McCann, S. M. (1978). Stimulation of growth hormone release by intraventricular administration of $5 \mathrm{HT}$ or quipazine in unanesthetized male rats. Proc. Soc. Exp. Biol. Med. 159, 210-212.

Wade, J. M., Juneja, P., Mackay, A. W., Graham, J., Havel, P. J., Tecott, L. H., et al. (2008). Synergistic impairment of glucose homeostasis in $\mathrm{ob} / \mathrm{ob}$ mice lacking functional serotonin 2C receptors. Endocrinology 149, 955-961.

Wade, P. R., Chen, J., Jaffe, B., Kassem, I. S., Blakely, R. D., and Gershon, M. D. (1996). Localization and function of a 5-HT transporter in crypt epithelia of the gastrointestinal tract. J. Neurosci. 16, 2352-2364.

Wade, P. R., Mawe, G. M., Branchek, T. A., and Gershon, M. D. (1991). Use of stereoisomers of zacopride to analyze actions of 5-hydroxytryptamine on enteric neurons. Am. J. Physiol. 260, G80-G90.

Walther, D. J., Peter, J. U., Bashammakh, S., Hortnagl, H., Voits, M., Fink, H., et al. (2003). Synthesis of serotonin by a second tryptophan hydroxylase isoform. Science 299, 76.

Wang, B., and Chehab, F. F. (2006). Deletion of the serotonin $2 \mathrm{c}$ receptor from transgenic mice overexpressing leptin does not affect their lipodystrophy but exacerbates their diet-induced obesity. Biochem. Biophys. Res. Commun. 351, 418-423.

Wang, L., Saint-Pierre, D. H., and Tache, Y. (2002). Peripheral ghrelin selectively increases Fos expression in neuropeptide $\mathrm{Y}$ - synthesizing neurons in mouse hypothalamic arcuate nucleus. Neurosci. Lett. 325, 47-51.

Wang, Q. P., Koyama, Y., Guan, J. L., Takahashi, K., Kayama, Y., and Shioda, S. (2005). The orexinergic synaptic innervation of serotoninand orexin 1-receptor-containing neurons in the dorsal raphe nucleus. Regul. Pept. 126, 35-42.

Ward, R. P., Hamblin, M. W., Lachowicz, J. E., Hoffman, B. J., Sibley, D. R., and Dorsa, D. M. (1995). Localization of serotonin subtype 6 receptor messenger RNA in the rat brain by in situ hybridization histochemistry. Neuroscience 64, 1105-1111.

Warden, S. J., Robling, A. G., Sanders, M. S., Bliziotes, M. M., and Turner, C. H. (2005). Inhibition of the serotonin (5-hydroxytryptamine) transporter reduces bone accrual during growth. Endocrinology 146, 685-693.
Watanabe, H., Akasaka, D., Ogasawara, H., Sato, K., Miyake, M., Saito, K., et al. (2010). Peripheral serotonin enhances lipid metabolism by accelerating bile acid turnover. Endocrinology 151, 4776-4786.

Werry, T. D., Loiacono, R., Sexton, P. M., and Christopoulos, A. (2008). RNA editing of the serotonin 5HT2C receptor and its effects on cell signalling, pharmacology and brain function. Pharmacol. Ther. 119, 7-23.

Willesen, M. G., Kristensen, P., and Romer, J. (1999). Co-localization of growth hormone secretagogue receptor and NPY mRNA in the arcuate nucleus of the rat. Neuroendocrinology 70, 306-316.

Williams, K. W., Margatho, L. O., Lee, C. E., Choi, M., Lee, S., Scott, M. M., et al. (2010). Segregation of acute leptin and insulin effects in distinct populations of arcuate proopiomelanocortin neurons. J. Neurosci. 30 2472-2479.

Williams, K. W., Scott, M. M., and Elmquist, J. K. (2011). Modulation of the central melanocortin system by leptin, insulin, and serotonin: co-ordinated actions in a dispersed neuronal network. Eur. J. Pharmacol. 660, 2-12.

Willoughby, J. O., and Blessing, W. W. (1987). Origin of serotonin innervation of the arcuate and ventromedial hypothalamic region. Brain Res. 418, 170-173

Willoughby, J. O., Menadue, M. F., and Liebelt, H. (1987). Activation of serotonin receptors in the medial basal hypothalamus stimulates growth hormone secretion in the unanesthetized rat. Brain Res. 404, 319-322.

Woods, S. C., Lotter, E. C., McKay, L. D., and Porte, D. Jr. (1979). Chronic intracerebroventricular infusion of insulin reduces food intake and body weight of baboons. Nature 282, 503-505.

Woolley, D. W., and Shaw, E. (1954). A biochemical and pharmacological suggestion about certain mental disorders. Proc. Natl. Acad. Sci. U.S.A. 40, 228-231.

Woolley, M. L., Bentley, J. C., Sleight, A. J., Marsden, C. A., and Fone, K. C. (2001). A role for 5-ht6 receptors in retention of spatial learning in the Morris water maze. Neuropharmacology 41, 210-219.

Wren, A. M., Small, C. J., Ward, H. L., Murphy, K. G., Dakin, C. L., Taheri, S., et al. (2000). The novel hypothalamic peptide ghrelin stimulates food intake and growth hormone secretion. Endocrinology 141, 4325-4328.
Wright, D. E., Seroogy, K. B., Lundgren, K. H., Davis, B. M., and Jennes, L. (1995). Comparative localization of serotonin1A, 1C, and 2 receptor subtype mRNAs in rat brain. J. Comp. Neurol. 351, 357-373.

Xie, E., Zhu, L., Zhao, L., and Chang, L. S. (1996). The human serotonin 5-HT2C receptor: complete cDNA, genomic structure, and alternatively spliced variant. Genomics 35 , 551-561.

$\mathrm{Xu}$, Y., Berglund, E. D., Sohn, J. W., Holland, W. L., Chuang, J. C., Fukuda, M., et al. (2010a). 5-HT(2C)Rs expressed by proopiomelanocortin neurons regulate insulin sensitivity in liver. Nat. Neurosci. 13, 1457-1459.

Xu, Y., Jones, J. E., Lauzon, D. A., Anderson, J. G., Balthasar, N., Heisler, L. K., et al. (2010b). A serotonin and melanocortin circuit mediates D-fenfluramine anorexia. J. Neurosci. 30, 14630-14634.

Xu, Y., Jones, J. E., Kohno, D., Williams, K. W., Lee, C. E., Choi, M. J., et al. (2008). 5-HT2CRs expressed by pro-opiomelanocortin neurons regulate energy homeostasis. Neuron 60, 582-589.

Yadav, V. K., Oury, F., Suda, N., Liu, Z. W., Gao, X. B., Confavreux, C., et al. (2009). A serotonin-dependent mechanism explains the leptin regulation of bone mass, appetite and energy expenditure. Cell 138, 976-989.

Yadav, V. K., Oury, F., Tanaka, K. F., Thomas, T., Wang, Y., Cremers, S., et al. (2011). Leptin-dependent serotonin control of appetite: temporal specificity, transcriptional regulation, and therapeutic implications. J. Exp. Med. 208, 41-52.

Yakabi, K., Sadakane, C., Noguchi, M., Ohno, S., Ro, S., Chinen, K., et al. (2010). Reduced ghrelin secretion in the hypothalamus of rats due to cisplatin-induced anorexia. Endocrinology 151, 3773-3782.

Yamada, J., Sugimoto, Y., Hirose, H., and Kajiwara, Y. (2003). Role of serotonergic mechanisms in leptin-induced suppression of milk intake in mice. Neurosci. Lett. 348, 195-197.

Yamada, J., Sugimoto, Y., Kimura, I., Takeuchi, N., and Horisaka, K. (1989). Serotonin-induced hypoglycemia and increased serum insulin levels in mice. Life Sci. 45, 1931-1936

Yamada, J., Sugimoto, Y., and Ujikawa, M. (1999). The serotonin precursor 5-hydroxytryptophan elevates 
serum leptin levels in mice. Eur. J. Pharmacol. 383, 49-51.

Yamada, J., Sugimoto, Y., and Ujikawa,

M. (2006). Involvement of lep-

tin in hypophagia induced

by the serotonin precursor

5-hydroxytryptophan (5-HTP)

in mice. Biol. Pharm. Bull. 29, 557-559.

Yamada, J., Sugimoto, Y., Yoshikawa, T., Kimura, I., and Horisaka, K. (1995).

The involvement of the peripheral

5-HT2A receptor in peripherally administered serotonin-induced hyperglycemia in rats. Life Sci. 57, 819-825.

Zhou, L., Sutton, G. M., Rochford, J. J., Semple, R. K., Lam, D. D., Oksanen, L. J., et al. (2007). Serotonin 2C receptor agonists improve type 2 diabetes via melanocortin-4 receptor signaling pathways. Cell Metab. 6, 398-405.

Conflict of Interest Statement: The authors declare that the research was conducted in the absence of any commercial or financial relationships that could be construed as a potential conflict of interest.

Received: 05 November 2012; accepted: 03 March 2013; published online: 27 March 2013.

Citation: Donovan $\mathrm{MH}$ and Tecott LH (2013) Serotonin and the regulation of mammalian energy balance. Front. Neurosci. 7:36. doi: 10.3389/fnins. 2013.00036
This article was submitted to Frontiers in Neuroendocrine Science, a specialty of Frontiers in Neuroscience.

Copyright (c) 2013 Donovan and Tecott. This is an open-access article distributed under the terms of the Creative Commons Attribution License, which permits use, distribution and reproduction in other forums, provided the original authors and source are credited and subject to any copyright notices concerning any third-party graphics etc. 